\title{
Późnogotyckie kościoły typu wieluńskiego - problem identyfikacji, uwarunkowań genetyczno-osadniczych i współczesnych walorów kulturowych
}

\begin{abstract}
Zarys treści: Rozdział dotyczy problemu identyfikacji, uwarunkowań genetyczno-osadniczych i współczesnych walorów kulturowych późnogotyckich, drewnianych kościołów reprezentujących odmianę wieluńską. Tworzą one homogeniczny, zwarty przestrzennie i specyficzny pod względem fizjonomicznym zbiór obiektów sakralnych o metryce szesnastowiecznej. W wyniku dyskusji i wskazaniu jednoznacznych kryteriów klasyfikacyjnych dokonano identyfikacji 10 zachowanych obiektów sakralnych tego typu. Na podstawie źródeł historycznych oraz literatury przedmiotu przeprowadzono analizę pochodzenia tytułowej grupy kościołów, uwzględniając kwestie administracji kościelnej i stosunków osadniczo-własnościowych. Następnie zbadano lokalizację oraz walory architektoniczne świątyń, biorąc pod uwagę zmienność form konstrukcyjno-dekoracyjnych oraz współczesny stan zachowania. Analizowane obiekty wykazują wybitne walory kulturowe w skali całego kraju, a nawet Europy i z tego względu wymagają szczególnej troski i podjęcia kompleksowych działań w zakresie ochrony prawno-konserwatorskiej.
\end{abstract}

Słowa kluczowe: kościół, ziemia wieluńska, XVI w., osadnictwo, dziedzictwo kulturowe.

\section{Wprowadzenie}

Obiekty sakralne różnych wyznań współtworzą współcześnie zręby krajobrazu kulturowego Polski. Stanowią emanację materialną jednego z najbardziej charakterystycznych elementów kultury duchowej, która odnosi się do sfery kultu religijnego. Jest to zasób wyjątkowo licznie reprezentowany i zróżnicowany wewnętrznie pod względem genetycznym, osadniczo-lokalizacyjnym i fizjonomicznym. Szczególnie cenne pod względem kulturowym są obiekty o stosunkowo dawnej metryce historycznej, obrazujące cechy następujących po sobie przez stulecia stylów architektonicznych. Zdecydowana większość tych świątyń podlega urzędowej ochronie prawno-konserwatorskiej. Warto w tym miejscu zaznaczyć, że spośród 64809 obiektów wpisanych do rejestru zabytków nieruchomych według Raportu o stanie zachowania zabytków nieruchomych w Polsce... (2017: 52), aż 11947 nieruchomości (tj. 18,44\% ogółu) pod względem funkcjonalnym odpowiada kategorii sakralnej. Choć przynależność wyznaniowa świątyń jest wyraźnie zróżnicowana, 
to z uwagi na wielowiekową tradycję rozwoju, sięgającą wczesnego średniowiecza oraz rangę w strukturach wyznaniowych ludności w ujęciu makroskalowym, kościoły związane z wiarą rzymskokatolicką stanowią najliczniejszą grupę zabytkowych obiektów sakralnych w Polsce. Obejmują one szerokie spektrum chronologiczne oraz reprezentowanych form architektonicznych. Szczególnie cenne w tym zakresie są pochodzące ze średniowiecza świątynie romańskie i gotyckie. Wiele $\mathrm{z}$ nich powstawało $\mathrm{w}$ tym samym okresie, w podobnych okolicznościach, według analogicznych wzorców konstrukcyjnych i dekoracyjnych. Niekiedy tworzą więc modelowe formy budownictwa sakralnego i cechują się dość wąską skalą przestrzenną swego występowania, co pozwala określić je mianem komponentów endemicznych krajobrazu kulturowego. Na uwagę zasługują przede wszystkim obiekty drewniane, gdyż ze względu na ograniczoną trwałość budulca, zachowały się w bardzo ograniczonym stopniu (Krassowski 1961; Tłoczek 1980; Chrzanowski, Piwocki 1981; Rączka 1990; Ruszczyk 2007). Wyodrębnić można wiele odmian, charakterystycznych dla poszczególnych regionów, które różnią się od siebie, biorąc pod uwagę chociażby kryterium kształtu planu przyziemia i programu wnętrza, liczby naw i ich wysokości czy formy dachu (Kornecki 1992). Dla przykładu warto wskazać homogeniczne kościoły drewniane z północnego Mazowsza, w okolicach Ciechanowa, Mławy i Wyszogrodu. Są to niewielkie, bezwieżowe świątynie, najczęściej dwudzielne, wzniesione na planie prostokąta z wyodrębnionym prezbiterium (Czerwiński 2010: 136-137). Do najciekawszych kościołów drewnianych o charakterze gotyckim należą obiekty zlokalizowane w południowej Małopolsce. Są to świątynie z kwadratową nawą i wydłużonym węższym od niej prezbiterium. Wyróżniały się wysokimi dachami krytymi gontem, izbicowymi dzwonnicami i szerokimi sobotami biegnącymi wzdłuż ścian zewnętrznych budynków (Brykowski 1981; Brykowski, Kornecki 1984). Z uwagi na wybitną wartość kulturową, część z nich zostało wpisanych w 2003 roku na Listę Światowego Dziedzictwa UNESCO (kościoły w Dębnie k. Nowego Targu, Dinarowej k. Jasła, Bliznem k. Brzozowa, Lipnicy Murowanej k. Bochni czy Sękowej k. Gorlic, Haczowie k. Krosna). Z omawianym typem koresponduje chronologicznie odmiana śląska, jednak w tym przypadku szerokość rozstawu krokwi dachowych w nawie jest inna niż dla węższego prezbiterium i dlatego dach nad nawą jest wyższy niż nad prezbiterium lub gdy obie części mają podobną wysokość, stromizna obu połaci dachowych jest różna (Matuszczak 1975).

Niezwykle interesującą grupę drewnianych kościołów późnogotyckich stanowią także świątynie zlokalizowane w okolicach Wielunia. Jest to niewielki liczebnie zbiór obiektów, powstałych na przełomie późnego średniowiecza i epoki wczesnonowożytnej, które oprócz zwartego i klarownego pod względem historycznym obszaru ich lokalizacji, cechują się względnym podobieństwem cech fizjonomicznych. Odmiana wieluńska kościołów wielkopolskich z tego okresu wyróżnia się nawą i prezbiterium nakrytym wspólnym, stromym dachem, ale 
o znacznie krótszych połaciach i bez sobót w porównaniu do świątyń w stylu małopolskim. Wieże przystawione na ogół do nawy są mniej masywne, nie mają izbic i nakryte są dachem brogowym. Analizowane obiekty z regionalnego punktu widzenia stanowią jeden z najcenniejszych elementów zasobu dziedzictwa kulturowego województwa łódzkiego. Nie oznacza to jednak, że doczekały się wnikliwej analizy porównawczej. Nie ma nawet zgodności wśród badaczy co do ich liczebności, gdyż wciąż jest wiele niejasności wynikających z braku jednoznacznych kryteriów klasyfikacyjnych. O ile poszczególne kościoły zostały w generalnym ujęciu rozpoznane pod względem architektonicznym, przede wszystkim na potrzeby ochrony prawno-konserwatorskiej, to już problem ich genezy w kontekście historyczno-osadniczym, lokalizacji względem otaczającej zabudowy i sieci komunikacyjnej nie zostały w dostatecznym stopniu zbadane. Skłoniło to autora do podjęcia studiów nad tym zagadnieniem z perspektywy geograficzno-historycznej.

Pierwszym celem szczegółowym rozdziału jest przeprowadzenie dyskusji na temat istoty drewnianych kościołów reprezentujących odmianę wieluńską, co może stanowić podstawę do identyfikacji poszczególnych obiektów na badanym obszarze dzięki wskazaniu klarownych kryteriów klasyfikacyjnych. Drugim celem pracy jest analiza pochodzenia tytułowej grupy świątyń, uwzględniając kwestie administracji kościelnej i stosunków osadniczo-własnościowych w okresie synchronicznym z powstaniem świątyń. Trzecim celem jest natomiast zbadanie głównych walorów fizjonomicznych oraz aktualnego stanu zachowania kościołów w stylu wieluńskim.

Na potrzeby rozdziału dokonano kwerendy materiałów historycznych w postaci źródeł pisanych o charakterze dokumentowym oraz opisowym z okresu średniowiecza i początków epoki nowożytnej, które pozwoliły na określenie genezy i kontekstu osadniczego powstania badanych obiektów. Ustalenie cech lokalizacyjnych możliwe było dzięki wykorzystaniu współczesnych danych przestrzennych (baza BDOT zaczerpnięta z geoportalu krajowego). W celu określenia walorów kulturowych posłużono się istniejącą dokumentacją konserwatorską oraz literaturą przedmiotu, a w celu ustalenia stopnia zachowania przeprowadzono w latach 2017-2019 lustrację terenową, która stanowiła jedną z głównych metod badawczych. Na potrzeby rozdziału posługiwano się ponadto klasycznymi metodami historycznymi, w tym metodą retrogresywną oraz metodami analizy kartograficznej.

\section{Problem identyfikacji kościołów typu wieluńskiego}

W literaturze przedmiotu, w której omawiane było zagadnienie kościołów drewnianych typu wieluńskiego dostrzec można wiele nieścisłości wynikających $\mathrm{z}$ braku jednoznacznych kryteriów klasyfikacyjnych. Podawana jest ich różna 
liczebność, a katalog poszczególnych obiektów przyporządkowanych do tej grupy w wielu przypadkach różni się od siebie, co prowadzi do nieporozumień. Ma to również swoje odzwierciedlenie w ogólnodostępnych materiałach upowszechnianych za pośrednictwem Internetu. Dla przykładu na stronie Regionalnego Katalogu Zabytków Województwa Łódzkiego do badanej kategorii zaliczone zostały kościoły w: Gaszynie, Grębieniu, Kadłubie, Łagiewnikach, Łaszewie, Naramicach, Popowicach, Wieluniu, Wierzbiu i Wiktorowie ${ }^{1}$. Na stronie Portalu Turystyki Aktywnej Ziemi Wieluńskiej do odmiany wieluńskiej przyporządkowano świątynie w: Gaszynie, Grębieniu, Kadłubie, Łaszewie, Łyskorni, Naramicach, Popowicach, Skomlinie, Wieluniu i Wiktorowie ${ }^{2}$. Dla porównania w ramach charakterystyki zabytków województwa łódzkiego na stronie Narodowego Instytutu Dziedzictwa wymienione zostały obiekty w: Gaszynie, Grębieniu, Kadłubie, Łaszewie, Łyskorni, Naramicach, Ochędzyniu, Popowicach, Wiktorowie ${ }^{3}$. Dostrzegalne na pierwszy rzut oka różnice skłoniły autora do podjęcia refleksji na temat cech konstytutywnych badanej kategorii kościołów. Oprócz wymienianych niemal w każdym źródle świątyń pojawiają się bowiem obiekty w innych lokalizacjach, co wymaga wyjaśnienia i doprecyzowania na potrzeby dalszej części rozdziału. Czasami wskazuje się wyłącznie kościoły zlokalizowane na terenie powiatu wieluńskiego lub tylko województwa łódzkiego, co można łatwo zweryfikować i ujednolicić. Niekiedy różnice są jednak efektem innego postrzegania istoty tej odmiany świątyń, biorąc pod uwagę kryterium metryki historycznej i cech konstrukcyjnych, co stwarza konieczność pogłębionej dyskusji na ten temat.

Po raz pierwszy na specyfikę drewnianych kościołów z XVI wieku w rejonie Wielunia zwrócił uwagę w okresie powojennym Jerzy Łoziński (1952). W świetle Katalogu zabytków sztuki w Polsce (1953) na obszarze ówczesnego powiatu wieluńskiego (o powierzchni znacznie większej od obecnej) zidentyfikowano 25 drewnianych kościołów pochodzących z różnych okresów historycznych, co czyniło go jednym $z$ najbogatszych w zabytki drewnianej architektury sakralnej w Polsce. Nie odnotowano żadnych strat w wyniku II wojny światowej, tym niemniej niektóre obiekty przestały istnieć już wcześniej, czego przykładem może być rozebrany w 1905 roku kościół w Dzietrznikach - fot. 1 (Brykowski 1994: 161). Od tego czasu szesnastowieczne kościoły drewniane z tego obszaru zaczęto umownie nazywać odmianą wieluńską (Krassowski 1961: 9; Ciekliński 1963: 18-39; Łoziński, Miłobędzki 1967: 19). Dalsze badania pozwoliły doprecy-

\footnotetext{
${ }^{1}$ Regionalny Katalog Zabytków Województwa Łódzkiego, http://www.kultura.lodz.pl/ $\mathrm{pl} / \mathrm{cms} /$ artykuly/zabytki/wdrewnie/drew_wielun/ (dostęp: 1.06.2020).

${ }^{2}$ Portal Turystyki Aktywnej Ziemi Wieluńskiej, http://www.turystyka.wielun.pl/pl/ cms/artykuly/co_inspiruje/kulturalnie/historyczna/zabytki/koscioly_wielun/ (dostęp: 1.06.2020).

${ }^{3}$ Portal Narodowego Instytutu Dziedzictwa, https://www.nid.pl/pl/Regiony/Lodzkie/ Zabytki_w_regionie/(dostęp: 1.06.2020).
} 


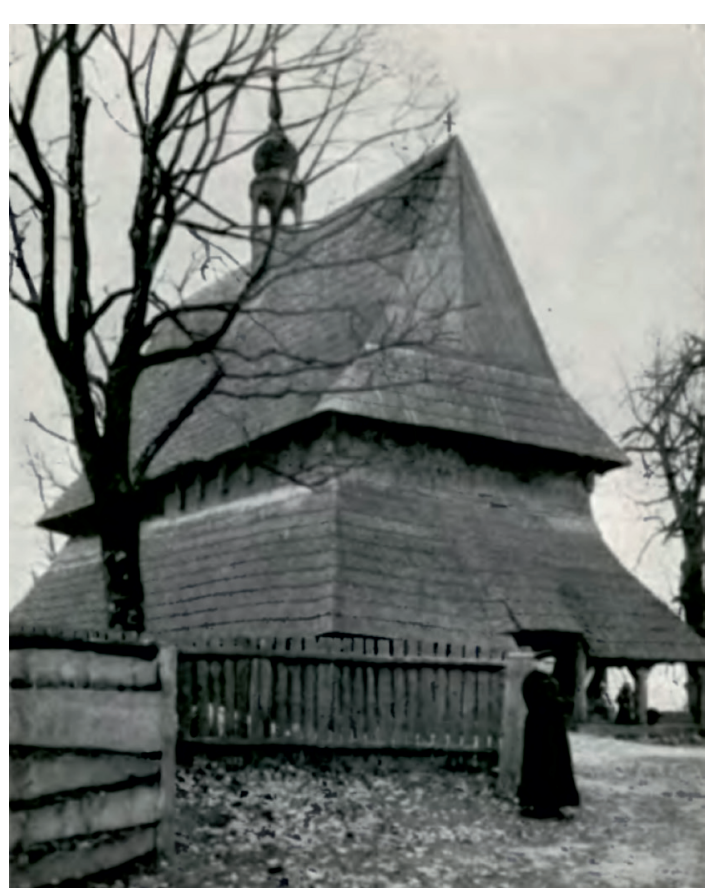

Fot. 1. Nieistniejący współcześnie kościół typu wieluńskiego w Dzietrznikach

Źródło: Budownictwo drzewne... (1905: 5), fot. K. Dietrich, dar B. Konratowiczowej

zować metrykę historyczną poszczególnych obiektów, dzięki czemu okazało się, że z XVI wiekiem należy wiązać pochodzenie 10 świątyń (Inwentarz drewnianej architektury sakralnej $w$ Polsce, 1993). Istotny głos w dyskusji na temat badanej grupy obiektów sakralnych przyniosła praca Mateusza Pawlaczyka (1984) poświęcona późnogotyckim kościołom drewnianym na terenie Wielkopolski. Przeprowadzona przez tego autora analiza cech stylowych świątyń dowiodła istnienia specyficznej grupy wielkopolskiej, której swoistą odmianą regionalną są kościoły wieluńskie. Są to obiekty posiadające formę jednokalenicową. Plan był złożony zasadniczo z dwóch elementów: kwadratowej nawy oraz węższego prezbiterium zamkniętego od wschodu wielobocznie, z ewentualnymi aneksami w postaci zakrystii od północy i kruchty od zachodu lub południa. Wnętrze miało charakter dwuczłonowy; bryła budynku była jednolita, której dominującym akcentem był stromy dwuspadowy dach z wydatnym okapem wokół prezbiterium. Choć formalnie kościoły te określane są mianem późnogotyckich, to zdaniem badacza należałoby raczej w stosunku do architektury drewnianej używać pojęcia gotycyzacji. Charakter stylowy gotyku posiadają w tych obiektach dekorowane snycerką belki, podciągi, profilowane obramienia, formy łuków tęczowych. O gotyckości kościoła drewnianego świadczyć mogą również niektóre elementy konstrukcyjne, typowe dla obiektów monumentalnych tego okresu, tj. konstrukcja storczykowa więźby z wzdłużnym usztywnieniem kratownicowym i co za tym idzie wysmukłe proporcje dachu. Kościoły wieluńskie w pełni realizują przedstawiony model 
kościoła jednokalenicowego odmiany wielkopolskiej, zarówno pod względem ukształtowania planu, przestrzeni wnętrza, bryły, jak i konstrukcji czy dekoracyjnego detalu architektonicznego (Pawlaczyk 1984: 109-110, 123, 129-130). Cechą typową dla kościółków wieluńskich są więc specyficzne rozwiązania techniczno-konstrukcyjne, polegające na zespoleniu nakrycia dwuczłonowej bryły budowli poprzez zastosowanie rozstawu krokwi odpowiadającego szerokości nawy, dzięki czemu wokół prezbiterium występował szeroki okap, podtrzymywany rzeźbionymi podporami (Kornecki 1992: 9).

Pozostaje jednak nadal kluczowe pytanie, czy przedstawione cechy konstrukcyjne są wystarczającym kryterium pozwalającym zaklasyfikować drewnianą świątynię w rejonie Wielunia do omawianej odmiany obiektów sakralnych. Otóż z całą pewnością nie, albowiem drewniane kościoły ziemi wieluńskiej nie stanowią kategorii równoznacznej z kościołami reprezentującymi późnogotyckie świątynie drewniane, które są przedmiotem niniejszych analiz. Dla ustalenia przynależności do odmiany wieluńskiej ważna jest bowiem także metryka historyczna obiektów. Chronologię w tym przypadku wyznaczają kościoły datowane mniej lub bardziej precyzyjnie na XVI wiek. Pozostałe świątynie drewniane powstały natomiast już znacznie później. Kościół w Łyskorni datuje się dopiero na 1660 r., w Białej i Skomlinie na lata 40. XVIII wieku, Rychłocicach na lata 70. XVIII wieku, a w Raczynie dopiero na połowę XIX wieku (Katalog zabytków sztuki w Polsce, 1953). Wymienione kościoły tylko częściowo nawiązywały do stylu wieluńskiego. Były to więc swoiste formy naśladowcze, a ich konstrukcja i cechy stylowe nie realizowały w pełni struktur wcześniejszego pochodzenia. Jak słusznie dostrzegł A. Ruszkowski (1992), w XVII i XVIII wieku pod wpływem kontrreformacji zaczęto budować obszerniejsze, często trójnawowe kościoły z barokowym wnętrzem, czego przykładem może być świątynia pw. św. Filipa i Jakuba zlokalizowana w Skomlinie. Zastąpiła ona wcześniejszy kościół, który spłonął w 1741 roku (Domagała 2004). Jego przyporządkowanie przez niektórych autorów do grupy wieluńskiej należy uznać za błędne, nie tylko ze względu na układ wnętrz, ale z uwagi na wyraźnie późniejszą datację. W przypadku Łyskoni kościół św. Marii Magdaleny spełnia wszystkie kryteria fizjonomiczne, lecz wykazuje z kolei, o czym wspomniano, znacznie późniejszą metrykę historyczną. Jest zatem formą naśladowczą. Z odwrotnego powodu dyskusyjna może być natomiast kwestia klasyfikacji kościoła pw. św. Jana Chrzciciela w Łagiewnikach. Powstał on ok. 1623 roku, a zdaniem cytowanego wcześniej M. Pawlaczyka (1984) typ wielkopolski kościołów, do których zaliczają się również kościoły wieluńskie, może obejmować także obiekty datowane na początek XVII stulecia. Jednakże w 1805 roku dziedzic Ignacy Ostrowski, ze względu na zniszczenie świątyni, polecił dokonać odbudowy obiektu w nowym miejscu (Langner 2014: 33-34). Biorąc pod uwagę powyższe przesłanki pominięto Łagiewniki w zestawieniu badanych obiektów, mimo że architektonicznie kościół w tej wsi nawiązuje do 
stylu wieluńskiego, ale faktycznie wykazuje znacznie późniejsze pochodzenie, ma bowiem formę jedynie nawiązującą do pierwotnej. Warto rozważyć również kwestię klasyfikacji kościoła cmentarnego św. Barbary na przedmieściach Wielunia (Białas 2008). Genezy tego obiektu można doszukiwać się w I połowie $\mathrm{XVI}$ wieku. Z tego stulecia pochodzi zresztą drewniane prezbiterium w konstrukcji zrębowej. W XIX wieku korpus budynku w postaci nawy został rozebrany, a na tym miejscu powstała konstrukcja murowana. Styl wieluński reprezentuje zatem tylko niewielki fragment budowli, a świątynia ta traktowana jako całość kompozycyjna utraciła swoje cechy stylowe, charakterystyczne dla formy drewnianych kościołów późnogotyckich.

Szczegółowe analizy objęły nie tylko kościoły spełniające wcześniej podane kryteria, które usytuowane są na obszarze obecnego powiatu wieluńskiego, ale szerzej na terenie historycznej ziemi wieluńskiej. Z tego powodu uwzględniono w badaniach także jeden obiekt połżony w powiecie wieruszowskim (Stary Ochędzyn) oraz jeden obiekt, który współcześnie leży już w graniach województwa opolskiego (Jaworzno i Wierzbie, w powiecie oleskim).

W świetle dotychczasowych rozważań do grupy świątyń typu wieluńskiego, zważywszy na metrykę historyczną i główne cechy stylowe, przyporządkowano następujące kościoły drewniane (w kolejności alfabetycznej, z uwzględnieniem wezwania i współczesnej przynależności gminnej):

1. Gaszyn, kościół pw. Najświętszego Imienia Maryi Panny, gm. Wieluń;

2. Grębień, kościół pw. Świętej Trójcy, gm. Pątnów;

3. Jaworzno, kościół pw. Trójcy Przenajświętszej, gm. Rudniki;

4. Kadłub, kościół pw. św. Andrzeja Apostoła, gm. Wieluń;

5. Łaszew, kościół pw. św. Jana Chrzciciela, gm. Wierzchlas;

6. Naramice, kościół pw. Wszystkich Świętych i Świętego Rocha, gm. Biała;

7. Ochędzyn Stary, kościół pw. św. Anny, gm. Sokolniki;

8. Popowice, kościół pw. Wszystkich Świętych, gm. Pątnów;

9. Wierzbie, kościół pw. Leonarda Opata, gm. Praszka;

10. Wiktorów, kościół pw. św. Zygmunta, gm. Biała.

\section{Kościoły typu wieluńskiego - kontekst genetyczno-osadniczy i walory kulturowe}

\section{Kościół pw. Najświętszego Imienia Maryi Panny w Gaszynie}

Wieś Gaszyn położona jest na Wyżynie Wieluńskiej, ok. $2 \mathrm{~km}$ na południe od Wielunia (w gminie Wieluń), przy drodze krajowej nr 45. Tworzy współcześnie układ wielodrożnicy. Pierwsze wzmianki na temat Gaszyna pochodzą z 1323 roku i odnoszą się do aktu sprzedaży sołectwa, w którym pojawia się informacja o Konradzie z Gaszyna (AGAD, Księgi grodzkie wieluńskie, 8, k. 40, za: Rosin 
1963: 80). W źródłach spotykane są różne formy nazwy wsi: Gazyn, Guszyno, Gasin, Gaschino. Powtarzają się w wielu dokumentach, ponieważ z analizowanej wsi pochodzili liczni urzędnicy ziemscy i sądowi (Rosin 1961: 156). W średniowieczu przez wieś przebiegał szlak handlowy z Moraw na Kujawy. W XVI wieku osada stanowiła własność kilku rodzin szlacheckich, w tym Gaszyńskich. W 1552 r., oprócz 3 łanów użytkowanych przez 19 chłopów, były również nadziały właścicieli (np. 3 łany Wierchlejskich). Folwark 2-łanowy posiadał również dziekan wieluński (Polska XVI wieku..., 1883: 288; Joannis de Lasco Liber beneficiorum ..., 1881: 96). W latach 20. XVII wieku część gruntów Gaszyńskich odsprzedana została konwentowi klasztoru S.S. Bernardynek. W 1719 roku bernardynki wykupiły resztę działów szlacheckich i tym samym stały się właścicielkami całej miejscowości aż do sekularyzacji dóbr kościelnych w 1796 roku (Zabraniak 2015: 419-420).

Kościół w Gaszynie powstał prawdopodobnie w połowie XVI wieku, brak jest jednak źródeł wskazujących na dokładną datę jego wzniesienia. Zastąpił on zapewne drewnianą kaplicę wzmiankowaną na początku XVI wieku (Joannis de Lasco Liber beneficiorum..., 1881: 94). Zbudowany został wówczas korpus nawowy, prezbiterium i zakrystia. Obiekt funkcjonował jako kaplica pw. św. Zygmunta Króla i Męczennika, należąca do klasztoru bernardynek, a obsługiwana przez wikariusza kolegiaty wieluńskiej. Była to budowla drewniana, kryta gontem, z wieżą przyległą do nawy z XVII wieku. W 1683 roku nastąpiło podniesienie kaplicy do rangi kościoła filialnego, czemu towarzyszyło nadanie nowego wezwania - Najświętszej Marii Panny Łaskawej. Prawdopodobnie miało to związek z ufundowaniem ołtarza i obrazu Matki Boskiej z Dzieciątkiem, będącego wotum wdzięczności za powrót $\mathrm{z}$ odsieczy wiedeńskiej. Z akt wizytacyjnych z końca XVIII wieku wynika, że kościół ponownie zmienił wezwanie, tym razem na Najświętszego Imienia Maryi i takie pozostało do dziś (Zabraniak 2015: 421). Dopiero w 1987 roku z parafii kolegiackiej w Wieluniu wyodrębniono oddzielną parafię gaszyńską. Należy ona do dekanatu Najświętszej Maryi Panny Pocieszenia w Wieluniu w archidiecezji częstochowskiej.

Kościół znajduje się w centralnej części wsi, pomiędzy dwiema osiami siedliskowymi. Jest to obiekt orientowany, usytuowany pośrodku cmentarza przykościelnego. Teren ogrodzony jest drewnianym parkanem i pierścieniem drzew, z okazałym wiązem w południowo-zachodnim narożniku. Omawiany obiekt sakralny jest drewniany, kryty gontem, z zewnątrz oszalowany. Elewacje rozczłonkowane są jedynie otworami okiennymi. Świątynia składa się z prostokątnej nawy i przylegającego do niej od wschodu węższego prezbiterium. Nawa i prezbiterium nakryte są wspólnym, jednokalenicowym, dwuspadowym dachem, z szerokim okapem wysuniętym wokół prezbiterium. W kalenicy nad nawą wznosi się sześcioboczna wieżyczka z sygnaturką. Ściany nawy i prezbiterium wzniesione są w konstrukcji wieńcowej, w węgłach na nakładkę i jaskółczy ogon. Nawę i prezbiterium wydziela otwór o prostokątnym wykroju, z fazowaną belką tęczową. 
Wnętrze nakryte jest płaskim stropem deskowo-listwowym. Na uwagę zasługuje późnorenesansowy ołtarz główny z I poł. XVII wieku, rzeźby św. Stanisława i św. Wojciecha (poł. XVII w.) oraz blacha trumienna Jakuba Gaszyńskiego (z 1672 r.). Od zachodu do nawy przylega niska wieża na planie kwadratu, nakryta dachem namiotowym, z wysuniętym okapem. Trzykondygnacyjna wieża posiada kruchtę w przyziemiu. Przy ścianie północnej prezbiterium usytuowana jest zakrystia, która zastąpiła starszą formę w latach 70 . XX wieku. Ściany wieży i zakrystii wzniesione zostały w konstrukcji słupowej. Wejście główne do kościoła znajduje się w zachodniej ścianie wieży, z dwoma węgarami i belką nadproża o półkolistym wykroju (Katalog zabytków sztuki w Polsce..., 1953: 365; Inwentarz drewnianej architektury sakralnej w Polsce..., 1993: 29, Cieślak 2014a).

Pierwsze prace remontowe przeprowadzono już w XVIII wieku. Podczas remontu kościoła w latach 1970-74 zlikwidowano część wyposażenia kościoła: usunięto polichromie, zdemontowano chór muzyczny, dwa ołtarze boczne oraz ambonę, a dobudowano nową zakrystię. W późniejszym czasie zakupione zostały nowe ławki, konfesjonał, ołtarz i chrzcielnica. Plac przykościelny oraz teren przeznaczony na parking został wyłożony kostką brukową (Strzelecki 2006: 46). Konserwacja kościoła miała miejsce w latach 2008-11, a w 2017 roku dokonano wymiany pokrycia dachu gontowego na nowy. Kościół parafialny pw. Najświętszego Imienia Maryi w Gaszynie podlega prawnej ochronie i uzyskał wpis do wojewódzkiego rejestru zabytków (nr rej.: 937 z 30.12.1967 r.). Świątynia jest obecnie zachowana w bardzo dobrym stanie.

\section{Kościół pw. Świętej Trójcy w Grębieniu}

Grębień usytuowany jest współcześnie w gminie Pątnów, w powiecie wieluńskim, ok. $10 \mathrm{~km}$ na południe od Wielunia. Ma obecnie formę rzędówki poregulacyjnej. Grębień, znany również z dokumentów jako Gramben, Grabyen i Grabien (Rosin 1963: 84), jest jedną z najstarszych miejscowości na terenie powiatu wieluńskiego. Pierwsza wzmianka pochodzi z 1299 roku i dotyczy darowizny, którą była część wsi przekazana arcybiskupowi gnieźnieńskiemu przez Stogniewa (Kodeks dyplomatyczny Wielkopolski, t. 2, 1878: nr 811, t. 3, 1879: nr 1488). W późniejszym czasie druga część wsi weszła we władanie arcybiskupa gnieźnieńskiego w drodze zamiany (Rosin 1961: 151). Lokacja na prawie niemieckim miała miejsce w 1323 roku, a pierwszym sołtysem został Santor (Wizytacje dóbr arcybiskupstwa gnieźnieńskiego..., 1920: 379-380). Wieś w okresie staropolskim stanowiła własność kościelną. W 1555 roku arcybiskup Mikołaj Dzierzgowski przekazał kapitule gnieźnieńskiej klucz wieluński, w tym również Grebień (Korytkowski 1889: 185-190). Według rejestrów podatkowych z 1552 roku odnotowano 13 kmieci na gruntach kościelnych, gospodarujących na 5 łanach ziemi. Oprócz tego funkcjonowało również gospodarstwo sołtysie (Polska XVI wieku ..., 1883: 301). 
Z II połowy XV wieku pochodzi informacja o istnieniu w Grębieniu kaplicy. Obecny kościół powstał prawdopodobnie w ostatnich latach XV lub na początku XVI wieku. Datowanie obiektu opiera się przede wszystkim na badaniach polichromii we wnętrzu: $z$ ok. 1500 roku pochodzi polichromia ścian, a z lat 1520-1531 polichromia stropu nawy i prezbiterium. Kościół nosił pierwotnie podwójne wezwanie: św. Jadwigi i św. Trójcy. W aktach wizytacyjnych z II połowy XVII wieku pojawia się już informacja o skróconym wezwaniu, tj. o kościele św. Trójcy (Lorenc-Karczewska 2014a). W 1719 roku grunty kościelne w Grębieniu przekazano proboszczowi w Kadłubie, nakładając na niego jednocześnie obowiązek remontowania świątyni. Opis uposażenia dóbr arcybiskupich z 1520 roku wskazuje, że świątynia znajdowała się na terenie parafii w Kadłubie (Joannis de Lasco Liber beneficiorum ..., 1881: 128). W XIX wieku kościół dwukrotnie zmieniał parafię: w 1827 roku na pątnowską, w 1863 roku na parafię w Krzyworzece, zaś od pierwszej dekady XX wieku do dziś należy do parafii Dzietrzniki jako kościół filialny. Administracyjnie wchodzi w skład dekanatu św. Wojciecha, Biskupa i Męczennika w Wieluniu.

Omawiany obiekt usytuowany jest w zachodniej części miejscowości, przy bocznej drodze w kierunku przysiółka Budziaki, ok. $150 \mathrm{~m}$ na południe od głównej drogi prowadzącej przez wieś ze wschodu na zachód. Teren kościelny z dawnym cmentarzem i starodrzewiem otoczony jest drewnianym ogrodzeniem. W latach 1810-1816 z fundacji Jana Świtały wzniesiono ponadto nową, stojącą do dziś dzwonnicę. Świątynia jest orientowana, zbudowana w konstrukcji zrębowej, z zewnątrz oszalowana. Jest to budowla z jedną nawą na planie zbliżonym do kwadratu, obejmująca nieco węższe i krótsze prezbiterium. Do ściany zachodniej nawy przylega trzykondygnacyjna wieża o konstrukcji słupowo-ramowej na planie kwadratu, poprzez którą wiedzie główne wejście do świątyni. Pokryta jest dachem namiotowym. Portal wejściowy jest profilowany w kształcie „oślego grzbietu”. Wzdłuż północnej ściany prezbiterium zlokalizowana jest zakrystia na planie prostokąta (w obecnej formie pochodząca z 1914 r.), zaś przy południowej ścianie nawy prostokątna kruchta (wymieniona po raz pierwszy w 1816 r., zastąpiona nową na pocz. XX w.). Nawa, prezbiterium, kruchta i zakrystia wieńczy wspólny dach dwupołaciowy, kryty gontem. Na jego szczycie znajduje się sygnaturka przykryta ostrosłupowym daszkiem. Ze względu na formę prezbiterium, dach tworzy nad nim okap wsparty na bogato zdobionych belkach stropowych. Ściany wewnątrz pokryte są polichromią. Drewniane stropy są płaskie, deskowe, na jednym poziomie w nawie i prezbiterium (Inwentarz drewnianej architektury sakralnej w Polsce..., 1993: 37-48; Lorenc-Karczewska 2014a; Strzelecki 2006: 51). W lustracji z 1763 roku znajduje się wzmianka o istnieniu w kościele chóru muzycznego $z$ organami. Wsparty jest on na trzech słupach. Przestrzeń nawy od prezbiterium symbolicznie dzieli profilowana belka tęczowa. Największą ozdobą jest zachowana we wnętrzu kościoła gotycko-renesansowa polichromia fundacji prymasa Jana Łaskiego z początku XVI wieku, która przedstawia w dwóch 
pasach sceny Męki Pańskiej. Malowidła w Grębieniu uważane są za jedne z najbardziej reprezentatywnych przykładów sztuki polskiej z tego okresu. Na szczególną uwagę zasługują nowatorskie, jak na owe czasy, świeckie motywy na sklepieniu kościoła, m.in. orzeł jagielloński i postacie grajków: dworskiego oraz plebejskiego w strojach z epoki. Na stropie nawy centralnym obiektem jest scena Zaśnięcia Matki Boskiej. Obok znajduje się św. Anna Samotrzeć, a po przeciwległej stronie stropu umieszczona jest postać św. Jadwigi Śląskiej. W prezbiterium strop jest ozdobiony polichromią z wizerunkiem Świętej Trójcy, herbami szlachty polskiej (Poraj i Leliwa) i kasetonami z rozetami (Wolf-Łozińska 1953; Olejnik 1980: 25-26; Langner 2014: 31-32). W ołtarzu głównym znajduje się gotycki tryptyk drewniany z XVI wieku z rzeźbami Matki Boskiej z Dzieciątkiem, św. Barbary i św. Mikołaja oraz gotycka rzeźba Boga Ojca na tronie. Ołtarze boczne mają charakter barokowy i pochodzą z XVIII wieku.

Obiekt podlegał do tej pory licznym renowacjom (np. 1720, 1752, 1780-1797, 1810-1816, 1900, 1914, 1950). Były to zarówno drobne prace konserwatorskie, jak i nieco poważniejsze przebudowy (przebudowa kruchty i zakrystii na początku XX w.). W latach 1952-1958 przeprowadzono badania i restaurację polichromii oraz wymianę gontów, a w latach 1998-2001 remont generalny kościoła obejmujący cały szalunek i poszycie oraz konserwację wyposażenia świątyni. Kościól filialny pw. Świętej Trójcy w Grębieniu podlega prawnej ochronie i uzyskał wpis do wojewódzkiego rejestru zabytków (nr rej.: 938 z 30.12.1967 r.). Świątynia jest obecnie zachowana $\mathrm{w}$ bardzo dobrym stanie.

\section{Kościół pw. Trójcy Przenajświętszej w Jaworznie}

Jaworzno to wieś położona $22 \mathrm{~km}$ na południe od Wielunia i ok. $25 \mathrm{~km}$ na północny wschód od Olesna. Z historycznego punktu widzenia była to osada przynależąca do ziemi wieluńskiej. W sensie administracyjnym współcześnie usytuowana jest na terenie gminy Rudniki, w powiecie oleskim, znajdującym się w północnej części województwa opolskiego. Wieś tworzy obecnie układ wielodrożnicy. Pierwsza wzmianka pisana na temat miejscowości kojarzona jest $\mathrm{z}$ dokumentem wystawionym przez papieża Innocentego IV z 1250 roku, zatwierdzającym posiadłości klasztoru na Piasku we Wrocławiu oraz jego filii w Mstowie. W grupie wsi, które płaciły dziesięciny z łanów kmiecych klasztorowi filialnemu kanoników regularnych pojawia się nazwa „Javorovo”, którą R. Rosin (1961: 134-135) identyfikuje ze współczesnym Jaworznem. Była to osada stanowiąca własność szlachecką, w II połowie XV wieku należała do rodu Kobylańskich herbu Grzymała (Rosin 1963: 86). W rejestrach podatkowych z lat 1552-1553 odnotowano 20 kmieci użytkujących 6 łanów ziemi, a ponadto jeden łan należący do sołtysa, co stanowi przesłankę źródłową, że wieś przeszła lokację na prawie niemieckim (Polska XVI wieku ..., 1883: 299). 
Istnienie parafii w Jaworznie udokumentowane jest od 1453 roku (Patykiewicz 1958: 282). Potwierdzają to również informacje pochodzące z wizytacji kościelnej z 1470 roku, gdy mowa jest o dziesięcinach pobieranych z łanów folwarcznych przez miejscowego plebana (Joannis Dlugossii..., 1864: 154). Obecny kościół został zbudowany na początku XVI wieku. W tym okresie samodzielna parafia w Jaworznie uległa likwidacji i została wcielona do parafii w Parzymiechach, na co wskazują zapiski z 1520 roku (Joannis de Lasco Liber beneficiorum ..., 1881: 115). Taki stan trwał do początków XX wieku, kiedy to 9 listopada 1919 roku biskup Stanisław Zdzitowiecki reerygował ponownie parafię. Należy ona do dekanatu krzepickiego w archidiecezji częstochowskiej.

Kościół w Jaworznie znajduje się w północnej części wsi, w bliskiej odległości od zwartej zabudowy, ok. $200 \mathrm{~m}$ od drogi $\mathrm{nr}$ 42. Otoczony jest cmentarzem $\mathrm{z}$ drewnianą dzwonnicą $\mathrm{w}$ północno-wschodnim narożu oraz starodrzewiem. Dzwonnica z lat 70. XX wieku jest murowana, oszalowana drewnem, zbudowana na planie kwadratu i zwieńczona namiotowym dachem. Teren kościelny wyznacza ogrodzenie murowane z granitu z lat 1986-88. Świątynia to obiekt orientowany, zbudowany z drewna modrzewiowego w konstrukcji zrębowej, z zewnątrz oszalowany. Kościół jest jednonawowy. Mniejsze od nawy prezbiterium jest zamknięte trójbocznie i łączy się z zakrystią od strony północnej. Od południa do nawy przylega prostokątna kruchta. Dach kościoła jest jednokalenicowy, dwuspadowy, kryty gontem, z szerokim okapem nad prezbiterium. Na dachu, nad nawą, znajduje się blaszana wieżyczka na sygnaturkę. W części frontowej usytuowana jest wieża wykonana w konstrukcji słupowej, z kruchtą w przyziemiu. Zwieńczona jest dachem namiotowym i blaszanym hełmem z latarnią. Kościół w wyniku rozbudowy przyjął wtórnie plan krzyża łacińskiego. Jego ramiona tworzą boczne kaplice, zamknięte trójbocznie, o kalenicach niższych od nawy głównej. Kaplice mają dachy dwuspadowe, przechodzące w trójpołaciowe. Kaplica północna powstała w latach 60. XVIII wieku, zaś południowa w latach 20. XX wieku. Wewnątrz usytuowany jest chór muzyczny, wsparty na dwóch słupach. Wyposażenie kościoła pochodzi w przeważającej mierze z przełomu XVII i XVIII wieku. W barokowym ołtarzu głównym znajduje się obraz Trójcy Świętej. Na uwagę zasługuje także ołtarz kaplicy bocznej z obrazem św. Teresy z XVIII wieku (Brykowski 2001: 30; Kalbarczyk-Klak 2014b).

Kościół w Jaworznie przeszedł liczne przebudowy i remonty, które zmieniły jego pierwotne oblicze architektoniczne. Został częściowo przebudowany ok. 1660 roku, a w 1767 roku dobudowano pierwszą kaplicę boczną. Podczas remontu w 1802 roku wykonano nowe pokrycie dachu, w 1887 roku oszalowano kościół z zewnątrz. W latach 1921-23 dokonano kontrowersyjnej rozbudowy nawy oraz utworzono drugą kaplicę, co zmieniło dotychczasowy, zwarty kształt kościoła. Gruntowny remont obiektu, obejmujący wymianę okien i oszalowanie wnętrza miał ponadto miejsce w latach 70 . XX wieku (Emmerling, Wierzgoń 
2006: 35). Kościół parafialny Trójcy Przenajświętszej w Jaworznie podlega prawnej ochronie i uzyskał wpis do wojewódzkiego rejestru zabytków (nr rej.: 939 z 30.12.1967 r.). Świątynia jest umiarkowanie zachowana z uwagi na dysharmonijną rozbudowę pierwotnej bryły omawianego obiektu sakralnego.

\section{Kościół pw. św. Andrzeja Apostoła w Kadłubie}

Kadłub to miejscowość położona $5 \mathrm{~km}$ na południe od Wielunia (na terenie gminy Wieluń). Usytuowana jest współcześnie przy drodze krajowej nr 45 ze Złoczewa przez Wieluń i Opole w kierunku granicy z Republiką Czeską. Reprezentuje obecnie układ dwustronnie zabudowanej ulicówki. Pierwsze zapiski źródłowe na temat wsi pochodzą z 1357 roku, kiedy to arcybiskup gnieźnieński Jarosław otrzymał od króla Kazimierza Wielkiego przywilej zatwierdzający wszystkie dobra ziemskie (Kodeks dyplomatyczny Wielkopolski, t. 3, 1879: nr 1354). Kadłub pozostał wsią kościelną przez cały okres staropolski (Rosin 1961: 159; 1963: 87-88). Osada przeszła lokację na prawie niemieckim, o czym świadczy wzmianka z 1441 roku na temat przywileju odnowienia wójtostwa, którego uposażenie wynosiło 4 łany ziemi (Wizytacje dóbr arcybiskupstwa gnieźnieńskiego..., 1920: 381). Zgodnie z rejestrami podatkowymi z lat 1552-1553 odnotowano w Kadłubie 14 kmieci gospodarujących na 12 1/4 łana ziemi (Polska XVI wieku ..., 1883: 301). W 1555 r. w rezultacie darowizny arcybiskupa Mikołaja Dzierzgowskiego wieś przeszła w posiadanie kapituły gnieźnieńskiej (Stownik geograficzny Królestwa Polskiego..., 1882: 659; Korytkowski 1889: 185-190).

Kościół św. Andrzeja został wzniesiony prawdopodobnie w początkach XVI wieku. Z wizytacji dóbr arcybiskupich uzyskujemy informację, że parafia w Kadłubie istniała już w XV wieku, a w 1520 roku gospodarstwo plebańskie obejmowało 2 łany ziemi (Joannis de Lasco Liber beneficiorum..., 1881: 126-127). Fatalna sytuacja finansowa parafii w 1827 roku skłoniła proboszcza do przeniesienia się do kościoła w Pątnowie. W 1847 roku budynek świątyni wskutek wieloletnich zaniedbań groził zawaleniem i dwa lata później z polecenia konsystorza piotrkowskiego kościół zamknięto. Dzięki restauracji budynku 7 maja 1851 roku świątynia została ponownie poświęcona i przywrócona do sprawowania kultu. W 1863 roku kościół w Kadłubie stał się formalnie filią parafii w Krzyworzece aż do 22 stycznia 1928 roku, kiedy to parafię restytuowano. Należy ona do dekanatu Najświętszej Maryi Panny Pocieszenia w Wieluniu, w archidiecezji częstochowskiej.

Obiekt sakralny znajduje się na niewielkim wzniesieniu, tuż przy drodze krajowej nr 43 Złoczew-Wieluń-Kluczbork-Opole, w bezpośrednim sąsiedztwie nowego, murowanego kościoła. Kościół otoczony jest starodrzewiem, wśród którego na szczególną uwagę zasługuje pomnikowy okaz lipy szerokolistnej, o obwodzie około $5 \mathrm{~m}$. Kościół jest orientowany, zbudowany z drewna modrzewiowego, w konstrukcji zrębowej. Ściany boczne są z zewnątrz oszalowane 
deskami. Świątynia ma charakter jednonawowy. Nawa i prezbiterium pokryte są wspólnym dachem jednokalenicowym, krytym gontem. Na jego szczycie znajduje się ośmioboczna wieżyczka na sygnaturkę, zwieńczona blaszanym hełmem baniastym z latarnią. Zamknięte trójbocznie prezbiterium jest nieco węższe od nawy, przez co dach tworzy niewielki okap wsparty na ozdobnych belkach (kroksztynach). Do prezbiterium przylega bezpośrednio zakrystia, zaś z boku nawy od strony zachodniej znajduje się kruchta, dobudowana w latach 1948-1949. Obok kościoła znajduje się metalowa dzwonnica, kryta daszkiem dwuspadowym, z dzwonem pochodzącym z XV wieku, opatrzonym napisem w języku łacińskim. W wyniku nieudolnej przebudowy po II wojnie światowej obiekt zatracił część swych cech stylowych. Elementem wyróżniającym go wśród pozostałych kościółków typu wieluńskiego był brak wieży od strony zachodniej, a w jej miejsce dobudowano przedłużenie nawy. W rezultacie smukła sylwetka kościoła stała się bardziej przysadzista. Przeprowadzony na początku tego wieku generalny remont doprowadził do rekonstrukcji wieży, która jest wkomponowana w bryłę kościoła jako przedłużenie nawy. Jest ona jednak znacznie obniżona w stosunku do pierwotnej formy. Zbudowana została na planie kwadratu i zwieńczona gontowym dachem namiotowym. We wnętrzu zachował się bogato zdobiony ołtarz główny z 1723 roku, którego centralnym punktem jest obraz Matki Boskiej z Dzieciątkiem. Wyróżniają się ponadto barokowe ołtarze boczne z rzeźbami świętych, ambona z ludową rzeźbą Michała Archanioła oraz belka tęczowa z krucyfiksem, a ponadto wsparty na dwóch słupach chór muzyczny (Olejnik 1980: 26; Strzelecki 2006: 62).

Kościół podlegał wielokrotnym remontom i przebudowom, które zniekształciły jego pierwotną strukturę. W latach 20 . XVIII wieku miał miejsce remont i właśnie z tego okresu pochodzi barokowy wystrój wnętrza, włącznie z ołtarzem głównym. Kolejny, poważny remont świątyni miał miejsce w połowie XIX wieku. W 1948 roku rozpoczęto modernizację kościoła. Niestety, wskutek przebudowy zatracił on swój pierwotny wygląd. To wówczas zlikwidowano charakterystyczną wieżę i przedłużono nawę. Jak wcześniej wspomniano, ostatni remont z lat 2006-08 pozwolił częściowo przywrócić dawny wygląd kościoła. Kościół parafialny p.w. Świętego Andrzeja Apostoła w Kadłubie podlega prawnej ochronie i uzyskał wpis do wojewódzkiego rejestru zabytków (nr rej.: 303-XIV-17 z 28.04.1949 r. i 302 z 30.12.1967 r.). Stan techniczny obiektu przed remontem był zły, zaś obecnie stan zachowania omawianej świątyni można określić jako dobry.

\section{Kościół pw. św. Jana Chrzciciela w Laszewie}

Łaszew, dawniej znany pod nazwą Łaszów, to wieś położona współcześnie na terenie gminy Wierzchlas, w powiecie wieluńskim, ok. $12 \mathrm{~km}$ na południowy wschód od Wielunia. Obecnie obejmuje dwa elementy składowe: rzędowy układ Starej 
Wsi jako pozostałość osadnictwa sprzed regulacji w XIX wieku oraz obustronnie zabudowaną oś siedliskową w postaci Łaszewa Rządowego. Pierwsza wzmianka na temat miejscowości pochodzi z 1386 roku i odnosi się do postaci Radlona de Lessow, widniejącego jako świadek w dokumencie wydanym przez księcia Władysława Opolczyka (Rosin 1961: 167). Wieś była w posiadaniu szlachty. Na podstawie rejestrów podatkowych z lat 1552-1553 dowiadujemy się, że Łaszew zamieszkiwało 13 kmieci. Część gruntów tworzyła prywatne gospodarstwa szlacheckie (np. 2 łany ziemi należące do rodziny Starzechowskich). W tym czasie wieś obejmowała aż 5 właścicieli, w tym przedstawicieli rodu Łaszowskich, herbu Doliwa (Polska XVI wieku..., 1883: 295).

Pierwsze zapiski potwierdzające fakt istnienia parafii łaszewskiej pochodzą z 1459 roku (Rosin 1963: 109). Informację na temat kościoła św. Jana Chrzciciela w Łaszewie uzyskujemy w materiale źródłowym z 1520 roku (Joannis de Lasco Liber beneficiorum ..., 1881: 95, 100, 129). Metrykę historyczną świątyni potwierdzają również badania historyczno-architektoniczne. Analiza polichromii na stropie prezbiterium i nawy dowodzi, że obiekt powstał w latach 20. XVI wieku. Według ustaleń Czesława Krassowskiego z okresu budowy świątyni pochodzą: zrąb, podwaliny i stropy ścian nawy, prezbiterium oraz zakrystii, a także więźba dachowa, część konstrukcji wieżyczki, otwór tęczowy, trzy portale wewnętrzne z drzwiami i okuciami, a także chór muzyczny ze schodami (Lorenc-Karczewska 2014b). W latach 1811-1813 nastąpiła likwidacja parafii i kościół stał się filią kościoła w Mierzycach. Do ponownego erygowania parafii w Łaszewie doszło w 1991 roku. Administracyjnie wchodzi ona w skład dekanatu św. Wojciecha, Biskupa i Męczennika w Wieluniu, w archidiecezji częstochowskiej.

Drewniany kościół św. Jana Chrzciciela w Łaszewie powstał na niewielkim wzniesieniu poza zwartym terenem zabudowanym wsi, w części północnej, w obrębie Starej Wsi. Obiekt usytuowany jest tuż przy drodze lokalnej z Bieńca Małego do Strug Pątnowskich, na ogrodzonym terenie cmentarza. Kościół jest orientowany. Budowla ma konstrukcję zrębową i jest oszalowana. Jego kwadratowa nawa łączy się z węższym, zamkniętym wielobocznie prezbiterium, do którego przylega od północy zakrystia, kryta dachem pulpitowym. Przy południowej części nawy usytuowano kruchtę, pokrytą dachem trójpołaciowym. Dach, zwieńczony sygnaturką, ma charakter jednokalenicowy, kryty jest gontem i tworzący szeroki okap nad prezbiterium. Od zachodu do nawy przylega wieża o konstrukcji słupowej, której wysokość nie przekracza kalenicy nawy. Przykryta jest dachem namiotowym i zwieńczona iglicą. Wnętrze kościoła jest jednoprzestrzenne, a stropy nawy i prezbiterium są płaskie, usytuowane na jednym poziomie. Na profilowanej belce tęczowej znajduje się XVII-wieczny krucyfiks o charakterze ludowym. Strop zdobiony jest renesansową polichromią z połowy XVI stulecia. Podzielony jest na kasetony z rozetami, na których umieszczone są motywy kandelabrowe. $\mathrm{W}$ jednym $\mathrm{z}$ kasetonów znajduje się scena figuralna $\mathrm{z}$ klęczącą 
postacią fundatora. Cennym elementem wnętrza jest barokowy ołtarz obejmujący piętnastowieczną gotycką Pietę. Wyróżnia się ponadto szesnastowieczna chrzcielnica, zdobiona herbami. Ołtarze boczne pochodzą z XVII i XVIII wieku. Wzdłuż zachodniej ściany nawy znajduje się chór muzyczny, wsparty na dwóch słupach (Inwentarz drewnianej architektury sakralnej w Polsce..., 1993: 71-77; Strzelecki 2006: 88; Langner 2014: 35-36).

Omawiany obiekt poddawany był licznym restauracjom i przebudowom, m.in. w 1740 i 1778 roku, kiedy to dobudowano do niego boczną kruchtę. Na początku XX wieku przeprowadzono gruntowną renowację wieży oraz wnętrza świątyni. W latach 1965-1967 renowacji poddano polichromię na stropie prezbiterium i nawy. Na przełomie lat 80. i 90. ubiegłego stulecia przystąpiono do kapitalnego remontu kościoła, dokonując jego niemal całkowitej rekonstrukcji. Prace zakończono w 1996 roku, pokrywając kościół nowym gontem (Bąbka-Horbacz 1996). Kościół parafialny p.w. św. Jana Chrzciciela w Łaszewie podlega prawnej ochronie i uzyskał wpis do wojewódzkiego rejestru zabytków (nr rej.: 947 z 30.12.1967 r.). Obecny stan zachowania omawianej świątyni można określić jako dobry.

\section{Kościół pw. Wszystkich Świętych i Świętego Rocha w Naramicach}

Naramice to wieś leżąca obecnie na obszarze gminy Biała, w powiecie wieluńskim, $13 \mathrm{~km}$ na północny zachód od Wielunia. Zachowała do dziś układ dwustronnie zabudowanej ulicówki. Pierwsze wzmianki na temat miejscowości pochodzą z 1395 roku i związane są z postacią Jana Naremskiego, który świadczył na dokumencie dotyczącym nadania Kopydłowa (Rosin 1961: 170). Nazwa wsi w formie „Naramicze” pojawiała się systematycznie w zapisach źródłowych z początku XV wieku. Miejscowość stanowiła w okresie staropolskim własność szlachecką. Do połowy XV wieku wieś należała do rodziny Naremskich. W późniejszym czasie odnotowujemy w księgach grodzkich wieluńskich przedstawicieli innych rodów, będących w posiadaniu Naramic (m.in. Chochlowskich, Kępińskich). W 1553 roku do Walichnowskich należały grunty o powierzchni 19 łanów, odnotowano ponadto jeden łan sołtysi, który wskazywać może, że wieś musiała przejść lokację na prawie niemieckim. W tym czasie wieś zamieszkiwało 34 kmieci, a ponadto zagrodnicy i chałupnicy (Polska XVI wieku..., 1883: 292-293).

Fakt istnienia parafii w Naramicach potwierdzają zapiski źródłowe z $1472 \mathrm{r}$. Odnoszą się one do procesu, jaki wytoczył pleban karczmarzowi o wypas bydła (Rosin 1963: 121). Obecny kościół parafialny pw. Wszystkich Świętych w Naramicach został zbudowany ok. 1520 roku. Świadczą o tym również pośrednio materiały wizytacyjne $\mathrm{z}$ tego okresu, w których mowa jest ponadto o 2 łanach ziemi 
stanowiących uposażenie proboszcza (Joannis de Lasco Liber beneficiorum..., 1881: 153-154). Status parafialny kościół utrzymał w sposób nieprzerwany aż do czasów współczesnych. Należy ona do dekanatu Najświętszej Maryi Panny Pocieszenia w Wieluniu, w archidiecezji częstochowskiej.

Świątynia usytuowana jest w zachodniej części wsi, pośrodku cmentarza przykościelnego, ogrodzonego drewnianym płotem. Teren otoczony jest starodrzewiem. Omawiany kościół jest orientowany, zbudowany z drewna modrzewiowego, w konstrukcji zrębowej. Ściany kościoła od zewnątrz są oszalowane. Obiekt składa się z prostokątnej nawy i nieco węższego, wydłużonego prezbiterium zamkniętego trójbocznie. Obie części przykryte są wysokim dachem, krytym gontem, co stanowi charakterystyczną cechę dla typu wieluńskiego. W kalenicy dachu nad nawą znajduje się ośmioboczna wieżyczka na sygnaturkę, zwieńczona hełmem blaszanym z latarnią. Do prezbiterium od strony północnej przylega zakrystia. Przy ścianie nawy usytuowana jest kaplica boczna założona na planie prostokąta, a od południa niewielka kruchta na planie kwadratu. Nad kaplicą i kruchtą południową dachy są trójpołaciowe. Od zachodu do nawy przylega późniejsza chronologicznie, bo pochodząca z XVIII wieku, prostokątna kruchta, poprzedzona sienią. Kruchtę tę oraz niższą od niej sień przykrywają dachy dwuspadowe. Nowe elementy przedłużające nawę sprawiły, że świątynia utraciła swoją pierwotną, zwartą sylwetkę. Wnętrze utrzymane jest w stylu barokowym. $\mathrm{W}$ prezbiterium znajduje się pozorne sklepienie kolebkowe, w pozostałych pomieszczeniach zaś stropy są belkowe płaskie. Przy zachodniej ścianie nawy wznosi się chór muzyczny, wsparty na dwóch słupach. Pomiędzy nawą a prezbiterium jest otwór zamknięty od góry belką tęczową z XVII-wiecznym krucyfiksem. Na uwagę zasługuje wyposażenie świątyni, które obejmuje zespół ołtarzy, w tym ołtarz główny z 1765 roku z obrazem gotyckim Zaśnięcia Matki Boskiej datowany na ok. 1480 rok oraz ołtarze boczne z 2 połowy XVIII wieku, a szczególnie ołtarz umieszczony w północnej ścianie nawy. W pobliżu kościoła usytuowana jest murowana dzwonnica typu arkadowego z dwoma dzwonami z 1720 roku (Katalog zabytków sztuki w Polsce..., 1953: 11; Strzelecki 2006: 109; Cieślak 2014c).

Na przestrzeni dziejów kościół był poddawany renowacjom i rozbudowie. W trakcie remontu trwającego w latach 1770-72 dokonano rozbudowy nawy o dwuczęściową kruchtę zachodnią. Kolejne prace konserwatorskie przeprowadzono na początku XIX i w XX wieku (np. w latach 1980-81 polegające na wymianie gontów). Kościół parafialny pw. Wszystkich Świętych w Naramicach podlega prawnej ochronie i uzyskał wpis do wojewódzkiego rejestru zabytków (nr rej.: 314-XIV-28 z 28.04.1949 r. oraz 310 z 30.12.1967 r.). Obecny stan zachowana omawianej świątyni można określić jako umiarkowany, z uwagi na brak wieży i wydłużoną kruchtę zachodnią. 


\section{Kościół pw. św. Anny w Ochędzynie Starym}

Stary Ochędzyn (odnotowywany w źródłach również jako Ochendzyno, Ochendzyn, Ochandzyn) to wieś położona współcześnie na terenie gminy Sokolniki, w powiecie wieruszowskim, $8 \mathrm{~km}$ na wschód od Wieruszowa. Obecnie ma formę jednostronnie zabudowanej rzędówki poregulacyjnej, której oś siedliskowa ma kształt linii łamanej. Jest to jedna z najstarszych miejscowości położonych na obszarze historycznej ziemi wieluńskiej. Pierwsza zapiska na temat osady pochodzi już z 1245 roku. Odnosi się ona do dokumentu, zgodnie z którym Wierzbięta z Gryfitów oraz Racława, wdowa po kasztelanie Klemensie, przekazali tę wieś, jak również Łubnice, Konarzewo, Pudliszki, Chróścin, Mieleszyn i Skomlin, na rzecz klasztoru cysterek z Ołoboku (Kodeks dyplomatyczny Wielkopolski, t. 1, 1877: nr 244; Rosin 1961: 133). Od tego czasu zakonnice były właścicielkami Ochędzyna aż do sekularyzacji dóbr kościelnych pod koniec XVIII wieku. W 1250 roku Przemysł I zezwolił klasztorowi dokonać lokacji wsi na prawie niemieckim (Kodeks dyplomatyczny Wielkopolski, t. 1, 1877: nr 281). Z rejestrów poborowych $\mathrm{z}$ lat 1552-1553 uzyskujemy informację na temat 13 kmieci gospodarujących na 6 łanach ziemi oraz jednym łanie sołtysim (Polska XVI wieku..., 1883: 302).

Według dokumentów źródłowych kaplica w Ochędzynie musiała istnieć co najmniej przed 1492 roku, o czym świadczy skarga sołtysa i kmieci na plebana z Sokolnik o niewypełnienie obowiązków (Rosin 1963: 124). Obecna świątynia pw. św. Anny jako kościół filialny została prawdopodobnie zbudowana na początku XVI wieku. Obecność kaplicy należącej ex antiquo do parafii Sokolniki poświadcza wzmianka pochodząca z 1520 roku (Joannis de Lasco Liber beneficiorum..., 1881: 151). Parafia w Ochędzynie erygowana została 12 czerwca 1922 roku, przez biskupa Stanisława Zdzitowieckiego. Należy obecnie do dekanatu wieruszowskiego diecezji kaliskiej.

Kościół położony jest w centralnej części wsi, w odległości około 1 km od drogi krajowej $\mathrm{nr} 8$. Usytuowany jest pośrodku placu otoczonego pierścieniem drzew i ogrodzonego murowanym parkanem. Wejście na teren kościoła prowadzi przez okazałą, murowaną bramę arkadową, która pełni równocześnie funkcję dzwonnicy. Została ona wzniesiona w latach 20. XX wieku. Świątynia jest obiektem orientowanym, jednonawowym, zbudowanym z drewna modrzewiowego. Kościół złożony jest z nawy, powiększonej od zachodu w 1925 roku, na planie wydłużonego prostokąta, zespolonej z węższym, zamkniętym trójbocznie prezbiterium, na planie zbliżonym do kwadratu. Dach jest jednokalenicowy, kryty gontem, nad prezbiterium tworzy szeroki okap, wsparty na filarach. W jego tylnej części usytuowana jest ośmioboczna wieżyczka na sygnaturkę z XVII wieku z baniastym hełmem z latarnią. Do prezbiterium od północy przylega zakrystia na planie prostokątnym. Zakrystię wieńczy jednospadowy dach będący przedłużeniem północnej połaci dachu prezbiterium. Do nawy zaś przylegają dwie kruchty: południowa 
(boczna) - na rzucie kwadratu i zachodnia (frontowa) - na rzucie prostokąta. Ściany prezbiterium i wschodniej części nawy wykonane są w konstrukcji zrębowej, zaś późniejsza, zachodnia część korpusu zbudowana została w konstrukcji szkieletowej. Pomiędzy prezbiterium i nawą znajduje się otwór z belką tęczową z rzeźbami zakonników, a przy zachodniej ścianie nawy jest XVIII-wieczny chór muzyczny, wsparty na dwóch słupach. Na ścianach wewnętrznych widnieją polichromie roślinne, zaś w prezbiterium przedstawiające Serce Jezusowe. Ołtarz główny ma metrykę późnorenesansową. Zawiera późnogotyckie figury z XVI wieku św. Anny Samotrzeć oraz śś. Barbary i Katarzyny. Dwa ołtarze boczne mają charakter barokowy i pochodzą z przełomu XVII i XVIII wieku (Inwentarz drewnianej architektury sakralnej w Polsce..., 1993: 89-98; Cieślak 2014b).

Bryła kościoła ukształtowana została na przełomie XV i XVI wieku, lecz była wielokrotnie remontowana. Podczas prowadzonego w latach 1780-97 remontu wzniesiono chór muzyczny. W 1925 roku powiększono korpus główny kościoła o 1/3, dobudowano kruchtę południową i oszalowano ściany. W 1945 roku pomalowano wnętrze kościoła oraz wymieniono pokrycie dachu. Ostatnia większa restauracja miała miejsce w 1994 roku. Kościół parafialny p.w. św. Anny w Starym Ochędzynie podlega prawnej ochronie i uzyskał wpis do wojewódzkiego rejestru zabytków (nr rej.: 8/315-XIV-29 z 28.04.1949 r. oraz 323 z 30.12.1967 r.). Obecny stan zachowana omawianej świątyni można określić jako umiarkowany (głównie ze względu na dysharmonijną rozbudowę nawy).

\section{Kościół pw. Wszystkich Świętych w Popowicach}

Popowice to miejscowość położona $7 \mathrm{~km}$ na południe od Wielunia, a pod względem administracyjnym usytuowana jest obecnie w gminie Pątnów, w powiecie wieluńskim. Obecnie osada ma formę rzędówki z wyraźną dominacją zabudowy po południowej stronie drogi. Popowice są jedną z najstarszych wsi w powiecie wieluńskim. Zgodnie $\mathrm{z}$ datowanym na lata 1236-1249 testamentem Jana, prepozyta z Rudy i kanonika gnieźnieńskiego, nieznaną z nazwy wieś zakupioną od synów Splotovica i Wojsława przekazano na rzecz kościoła św. Wojciecha w Rudzie (Codex Diplomaticus Silesiae..., 1884, t. 7, cz. 1: 480). W XIII wieku nastąpił upadek Rudy i przeniesienie kolegiaty do Wielunia. Zdaniem R. Rosina (1961: 133-134) kolegiata wieluńska posiadała tylko jedną wieś (Popowice), zatem metodą retrogresji można identyfikować omawianą osadę z darowaną przez prepozyta Jana. Wzmianka z 1459 roku na temat sołtysa daje podstawę, by twierdzić, że wieś przeszła w okresie średniowiecza lokację na prawie niemieckim (AGAD, Księgi grodzkie wieluńskie, 1, k. 35, za: Rosin 1963: 136). W świetle danych podatkowych z lat 1552-1553 uzyskujemy informację, że we wsi istniało 14 gospodarstw kmiecych, obejmujących po 1/2 łana ziemi, co daje łączny areał 7 łanów (Polska XVI wieku..., 1883: 301). 
Z wizytacji wykonanej w 1520 roku wynika, że wieś stanowiła uposażenie kanonii w Popowicach, podporządkowanej kolegiacie wieluńskiej, a przynależała pod względem administracji kościelnej do parafii w Kadłubie (Joannis de Lasco Liber beneficiorum ..., 1881: 101, 127). Kościół p.w. Wszystkich Świętych powstał prawdopodobnie na początku XVI wieku. Według przekazów źródłowych istniała w tym miejscu kaplica (oraculum), a nabożeństwo w niej odprawiał co trzecią niedzielę pleban z Kadłubia. W 1841 roku parafia w Kadłubiu wraz kościołami filialnymi w Popowicach i Grębieniu wcielona została do parafii w Krzyworzece (Stownik geograficzny Królestwa Polskiego..., t. 8, 1887: 799). Współcześnie omawiana świątynia stanowi ponownie kościół filialny parafii w Kadłubie (Olejnik 1980: 34). Należy ona do dekanatu Najświętszej Maryi Panny Pocieszenia w Wieluniu, w archidiecezji częstochowskiej.

Omawiany obiekt sakralny znajduje się przy głównej drodze, biegnącej przez Popowice, po jej północnej stronie. Obok kościoła rośnie cenny starodrzew, w tym m.in.: lipy i wiązy. Świątynia jest orientowana, ma charakter jednonawowy, wykonana została w konstrukcji zrębowej, a ściany zewnętrzne zostały oszalowane. Nawa i prezbiterium wybudowane zostały na rzutach zbliżonych do kwadratów. Prezbiterium, podobnie jak we wszystkich kościołach reprezentujących typ wieluński, jest węższe, zamknięte od zachodu trójbocznie. Od północy przylega do niego zakrystia. $Z$ boku nawy usytuowana jest natomiast kruchta, o dwuspadowym dachu krokwiowym. Całość korpusu budowli pokrywa stromy dach jednokalenicowy, z ośmioboczną wieżyczką na sygnaturkę, zwieńczoną blaszanym hełmem i krzyżem. Wspólny dla nawy i prezbiterium dach, kryty gontem, tworzy nad prezbiterium szeroki okap wsparty na bogato rzeźbionych belkach stropowych. Od zachodu do nawy przylega trzykondygnacyjna wieża konstrukcji słupowo-ryglowej, niższa od bryły kościoła, zwieńczona dachem namiotowym. Obok świątyni znajduje się metalowa dzwonnica, otwarta, kryta daszkiem dwuspadowym. We wnętrzu zachowany jest renesansowy ołtarz główny z XVI wieku. Znajdują się w nim posągi świętych i obraz Matki Bożej Miłosierdzia. Ołtarze boczne pochodzą z I poł. XVIII wieku. Na belce tęczowej umieszczony jest krucyfiks pochodzący z XVII wieku. Na uwagę zasługują także późnogotyckie odrzwia prowadzące z kruchty południowej do nawy (Olejnik 1980: 34; Strzelecki 2006: 123; Langner 2014: 27-28). Kościół był wielokrotnie remontowany, m.in. w 1730, 1753 roku i w latach 1981-84. Kościół filialny pw. Wszystkich Świętych w Popowicach podlega prawnej ochronie i uzyskał wpis do wojewódzkiego rejestru zabytków (nr rej.: 950 z 30.12.1967 r.). Obecny stan zachowania omawianej świątyni można określić jako dobry. 


\section{Kościół pw. Leonarda Opata w Wierzbiu}

Wierzbie to wieś w położona $10 \mathrm{~km}$ od Wielunia i $30 \mathrm{~km}$ na północny wschód od Olesna. Współcześnie znajduje się na obszarze województwa opolskiego, w powiecie oleskim, w gminie Praszka, przy drodze krajowej nr 45 z Wielunia do Opola. Obecnie ma postać układu ulicowego o zwartej, obustronnej zabudowie. Jest to miejscowość, w odniesieniu do której można precyzyjnie ustalić datację i okoliczności powstania na podstawie aktu lokacyjnego wydanego przez księcia Władysława Opolczyka w 1381 roku. Wierzbie zostało założone na tzw. surowym korzeniu. Osadnikom zezwolono wykarczować i rozmierzyć 19 łanów ziemi, dla sołtysa przeznaczono zaś nadział o powierzchni 3 łanów. Kmiecie uzyskali 12 lat wolnizny w inicjalnym okresie rozwoju osady (Patykiewicz 1958: 278-279; Rosin 1961: 166). Wieś stanowiła własność dóbr królewskich i w okresie staropolskim wchodziła w skład starostwa wieluńskiego. W okresie sporządzania rejestrów poborowych w latach 1552-1553 odnotowano 5 łanów kmiecych i jeden sołtysi, pozostałe grunty stanowiły zaś pogorzelisko (Polska XVI wieku..., 1883: 305).

Parafia w Wierzbiu istniała prawdopodobnie już w XV wieku. W materiałach źródłowych pochodzących z 1492 roku pojawia się informacja na temat kaplicy (Patykiewicz 1957: 429; Rosin 1963: 176). Za czasów arcybiskupa Jana Łaskiego parafia przestała istnieć i została podporządkowana administracyjnie pobliskiemu kościołowi parafialnemu w Ożarowie. Od tego czasu oraculum tituli S. Leonardi funkcjonował już jako świątynia filialna (Joannis de Lasco Liber beneficiorum..., 1881: 125). Badania historyczno-architektoniczne potwierdzają, że zrąb obecnego obiektu powstał ok. 1520 r. (Kalbarczyk-Klak 2014a). 12 stycznia 1902 roku parafia w Wierzbiu została reerygowana przez biskupa Stanisława Zdzitowskiego. Obecnie znajduje się w granicach dekanatu Mokrsko, w archidiecezji częstochowskiej.

Kościół w Wierzbiu położony jest w południowo-zachodniej części wsi, w pobliżu skrzyżowania głównej drogi z drogą do Ożarowa, od której oddzielony jest parkingiem i terenem zieleni. Jest to świątynia orientowana, jednonawowa, wykonana w konstrukcji zrębowej. Elewacje są oszalowane deskami w układzie pionowym. Węższe od nawy prezbiterium zamknięte jest prostokątnie i obejmuje dwie boczne zakrystie. Usytuowana wzdłuż północnej ściany prezbiterium zakrystia na planie prostokąta wraz przedsionkiem jest murowana i otynkowana. Od frontu i z boku nawy przylegają kruchty. Nawa i prezbiterium kryte są dwukalenicowym dachem gontowym, którego połacie przechodzą w dolnej części w dachy pulpitowe nad aneksami. Na szczycie znajduje się sześcioboczna wieżyczka na sygnaturkę z blaszanym hełmem. Od strony zachodniej na nawie osadzona jest czworoboczna wieża w konstrukcji słupowej, zwieńczona dachem namiotowym oraz niewielką sygnaturką. W zewnętrznych elewacjach znajdują się dwa masywne portale z XVI wieku. Obok kościoła znajduje się drewniana dzwonnica. Wnętrze cechuje się płaskimi stropami, wspólnymi dla nawy i prezbiterium. Ściany 
pokryte są roślinnymi polichromiami. Zachował się ołtarz główny z XVIII wieku z późnogotyckim tryptykiem oraz dwa ołtarze boczne, a ponadto barokowa ambona $\mathrm{z}$ wizerunkami Ewangelistów. Na uwagę zasługuje również wsparty na słupach chór muzyczny oraz belka tęczowa z krucyfiksem (Katalog zabytków sztuki w Polsce..., 1953; Olejnik 1980: 43; Kalbarczyk-Klak 2014a).

Kościół po raz pierwszy był przebudowany pod koniec XVIII wieku, następnie restaurowany wielokrotnie w latach $1889,1949,1971-74$ i odnowiony w latach 1994-2000. W 1959 roku wykonano prace, które zatarły w znacznym stopniu pierwotną formę świątyni. Poszerzono wówczas nawę i prezbiterium, dodając do nich aneksy oraz usunięto południową kruchtę. Wieża została włączona w bryłę kościoła poprzez obudowanie aneksami i przykrycie połaciami dachu nad nawą, zmieniono także formę otworów okiennych. Kościół parafialny pw. św. Leonarda w Wierzbiu podlega prawnej ochronie i uzyskał wpis do wojewódzkiego rejestru zabytków (nr rej.: 974 z 30.12.1967 r.). Obecny stan zachowana omawianej świątyni można określić jako umiarkowany (głównie z uwagi na dysharmonijną przebudowę w II połowie XX wieku).

\section{Kościól pw. św. Zygmunta w Wiktorowie}

Wiktorów to wieś leżąca obecnie na terenie gminy Biała, w powiecie wieluńskim, ok. $10 \mathrm{~km}$ na północny zachód od Wielunia, nad Oleśnicą, dopływem Warty. W sensie morfogenetycznym stanowi zniekształconą formę dawnej ulicówki, rozszerzoną o kolonijną zabudowę na peryferiach siedliska. Miejscowość znana jest z przekazów źródłowych od 1404 roku, kiedy to pojawia się wzmianka na temat Lutolda z „Wyctorowa” (Rosin 1961: 174). Wieś stanowiła własność szlachecką. Było to wówczas gniazdo znanego w Sieradzkiem rodu Wiktorowskich herbu Gryf. W świetle rejestrów poborowych z lat 1552-1553 odnotowano tu jedynie 4 kmieci użytkujących 11/2 łana ziemi (Polska XVI wieku ..., 1883: 297).

Kościół pw. św. Zygmunta w Wiktorowie powstał prawdopodobnie w pierwszej połowie XVI wieku, choć kaplica w tym miejscu istniała już na pewno w XV wieku, o czym świadczą zapiski w kościelnych aktach wizytacyjnych z 1520 roku. W okresie tym był to obiekt filialny należący do parafii św. Piotra w Okowach z Białej (Joannis de Lasco Liber beneficiorum..., 1881: 155). Taki status omawiany kościół zachował do czasów obecnych. Należy do dekanatu Wieluń - Najświętszej Maryi Panny Pocieszenia archidiecezji częstochowskiej.

Świątynia usytuowana jest w zachodniej części siedliska wsi, na niewielkiej działce, w pobliżu skupionej zabudowy zagrodowej. Kościół jest orientowany. Korpus budowli składa się z nawy i węższego w stosunku do niej, zamkniętego trójbocznie prezbiterium, do którego przylega boczna zakrystia. Bezpośrednio przy nawie znajduje się mała kruchta. Nawę i prezbiterium wieńczy wysoki dach jednokalenicowy tworzący szeroki okap nad częścią ołtarzową. Na szczycie da- 
chu, pokrytego gontem, widoczna jest sześcioboczna wieżyczka na sygnaturkę, zwieńczona blaszanym hełmem z latarnią. Od wielu innych, omawianych uprzednio kościołów odmiany wieluńskiej, obiekt odróżnia brak charakterystycznej wieży w części frontalnej. Wewnątrz zachowane są fragmenty polichromii figuralnej. Wyposażenie stanowią cenne obrazy, a wśród nich obraz Madonny z Dzieciątkiem, namalowany prawdopodobnie około 1470 roku przez Jana z Nysy oraz gotyckie malowidło przedstawiające Zwiastowanie Najświętszej Marii Panny, wykonane techniką olejną na płótnie i desce. Na uwagę zasługują ponadto trzy ołtarze i ambona pochodzące z ok. 1700 roku, a także kamienna chrzcielnica datowana na XVI wiek i belka tęczowa z krucyfiksem z XVII wieku. W barokowym ołtarzu głównym umieszczono trzy polichromowane rzeźby, a w ołtarzu bocznym znajduje się gotycki obraz Matki Bożej Bolesnej. Warto dodać, że przed kościołem usytuowana jest rzeźba Chrystusa i Matki Boskiej pod Krzyżem, wykonana w lipie przez ludowego artystę Janusza Ścigałę z Wiktorowa, a także metalowa dzwonnica, kryta daszkiem czterospadowym (Olejnik 1980: 43; Strzelecki 2006: 161; Langner 2014: 40-41).

Omawiana świątynia została po raz pierwszy przebudowana w 1760 r. przez właściciela wsi Mariana Zarębę. Zyskała wtedy nowe ołtarze i odrestaurowano podłogę. Podczas II wojny światowej obiekt został zdewastowany, a po jej zakończeniu zaniedbany popadał w ruinę. Staraniem księdza E. Malatyńskiego w latach 1976-87 kościół został gruntownie zrekonstruowany wraz z wyposażeniem wnętrza. Kościół filialny pw. św. Zygmunta w Wiktorowie podlega prawnej ochronie i uzyskał wpis do wojewódzkiego rejestru zabytków (nr rej.: 976 z 30.12.1967 r.). Obecny stan zachowania omawianej świątyni można określić jako dobry.

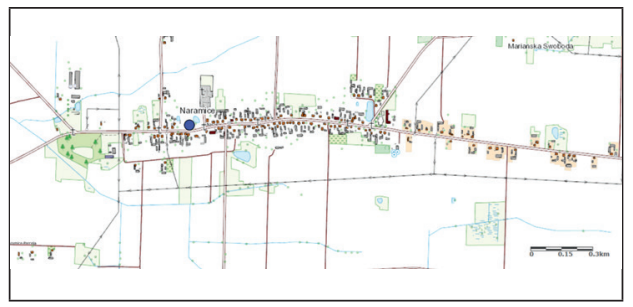

Naramice

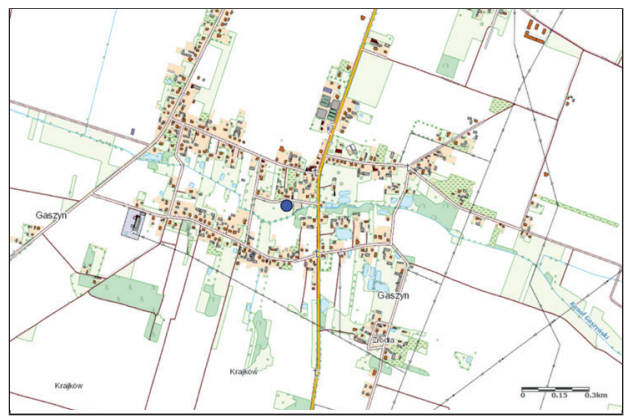

Gaszyn

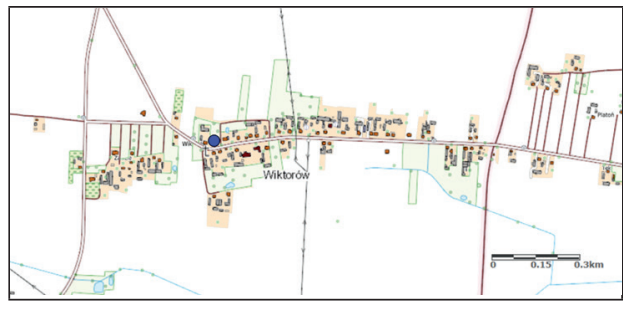

Wiktorów

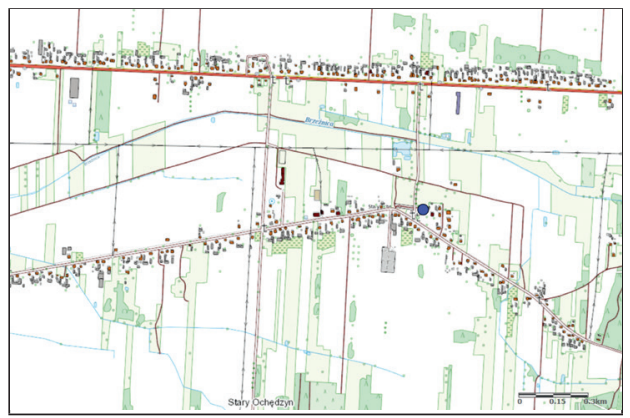

Ochędzyn Stary 


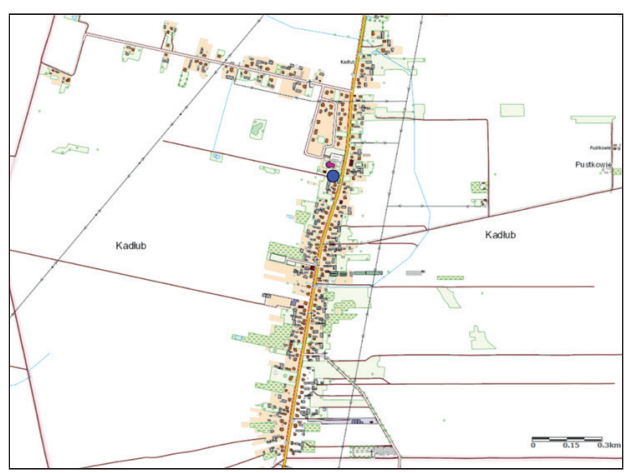

Kadłub

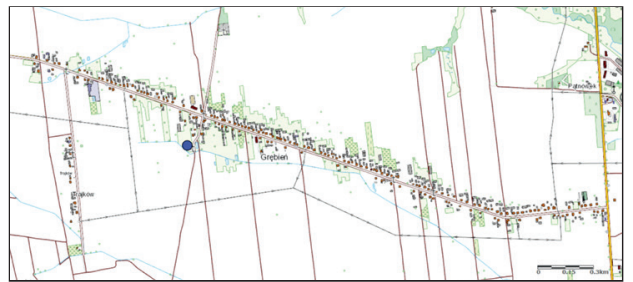

Grębień

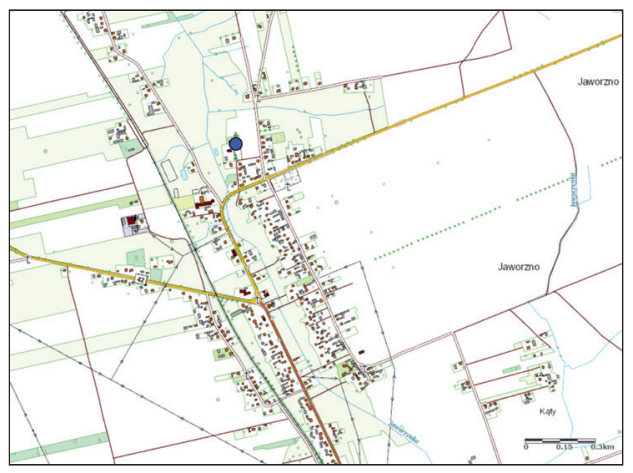

Jaworzno

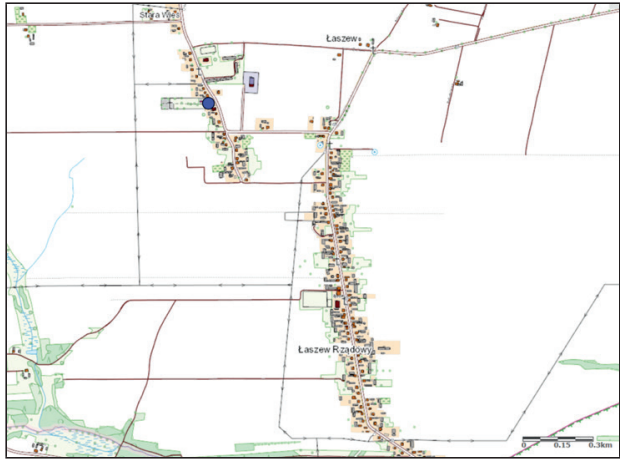

Łaszew

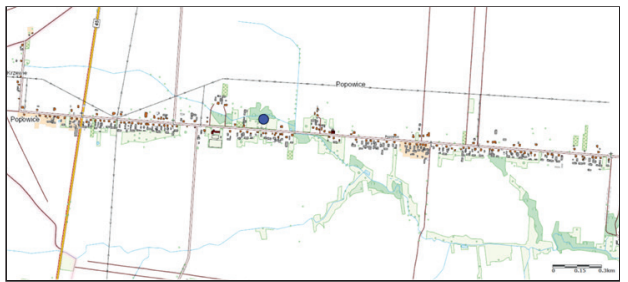

Popowice

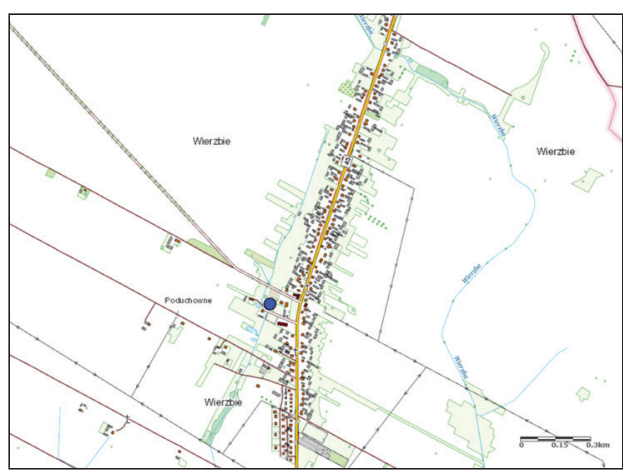

Wierzbie

Ryc. 1. Współczesna lokalizacja kościołów typu wieluńskiego w obrębie siedlisk wsi Źródło: oprac. własne na podkładzie wizualizacji BDOT10k, https://mapy.geoportal.gov.pl/ 
Późnogotyckie kościoły typu wieluńskiego - problem identyfikacji...

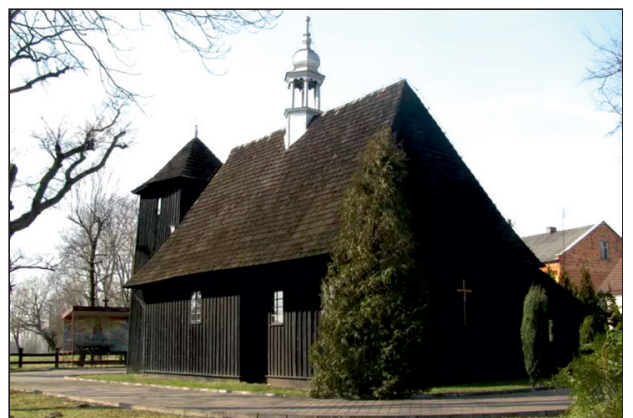

Gaszyn

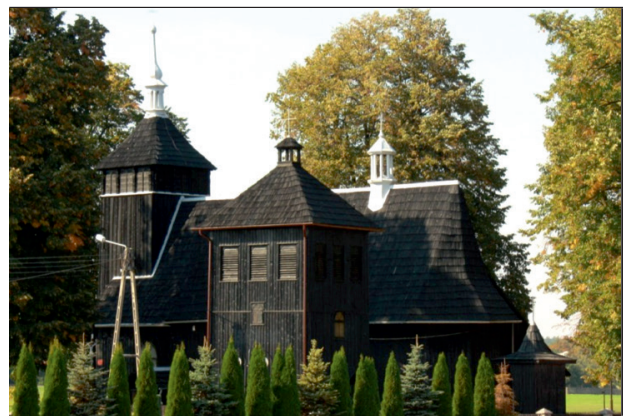

Jaworzno

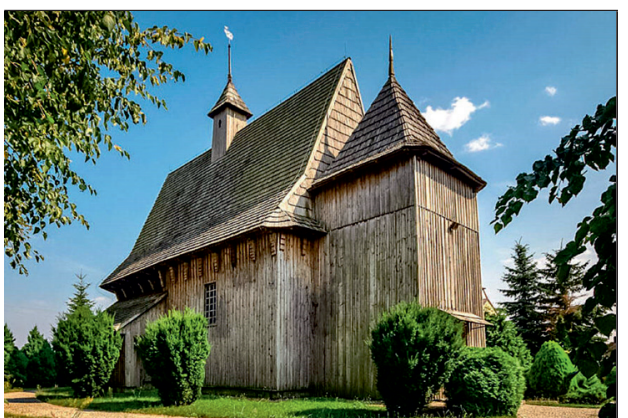

Łaszew

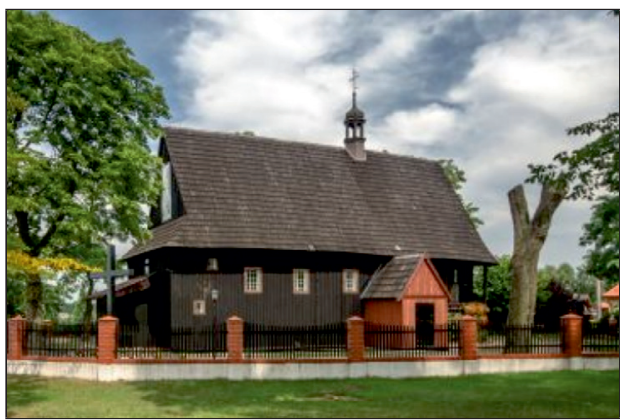

Ochędzyn Stary

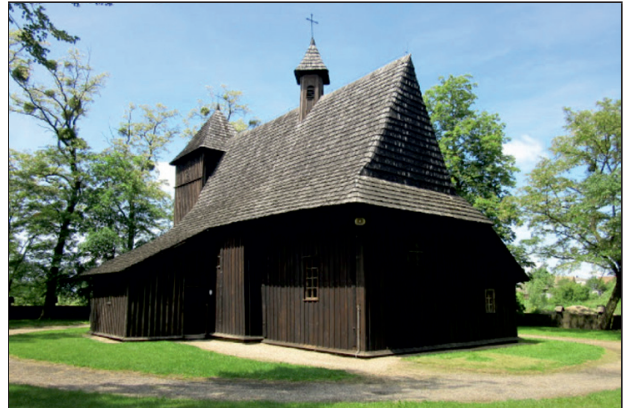

Grębień

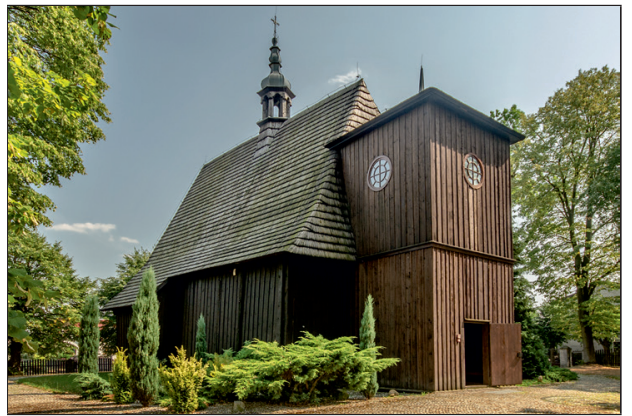

Kadłub

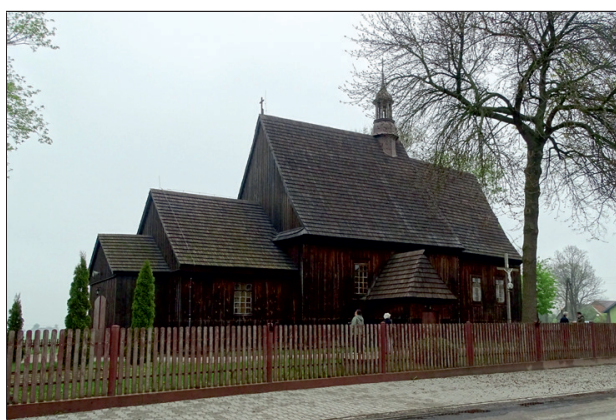

Naramice

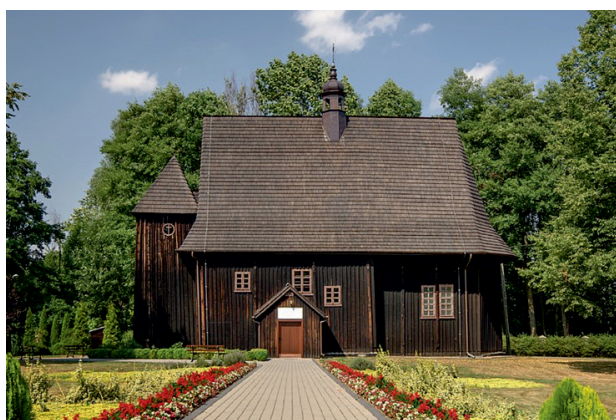

Popowice 


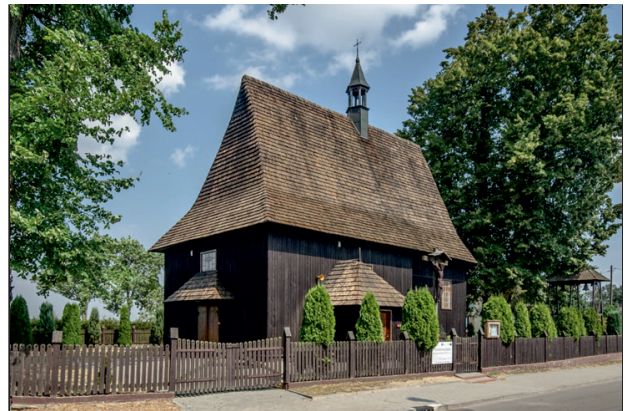

Wiktorów

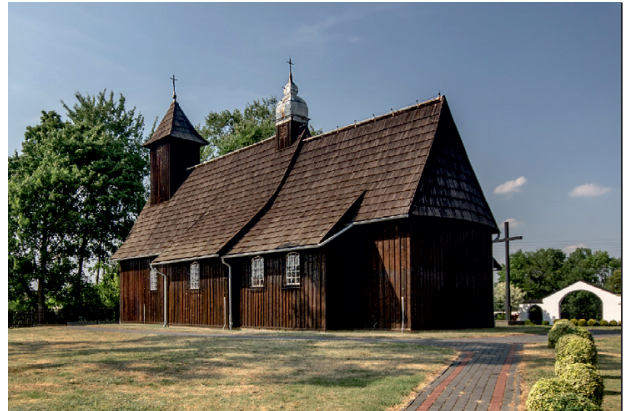

Wierzbie

Fot. 2. Współczesna fizjonomia kościołów typu wieluńskiego

Źródło: fot. T. Figlus

\section{Analiza porównawcza i podsumowanie}

Badana odmiana kościołów wiąże się ściśle z ich lokalizacją. Omówione w rozdziale obiekty sakralne o metryce szesnastowiecznej i specyficznych cechach fizjonomicznych powstały na terenie historycznej ziemi wieluńskiej. Przyjęła ona taką nazwę, gdy pod koniec XIII wieku przeniesiono siedzibę kasztelanii z Rudy do Wielunia. W okresie rozbicia dzielnicowego była władana przemiennie przez wielkopolskich i śląskich książąt piastowskich, a po zakończeniu rządów Władysława Opolczyka ziemię wieluńską przyłączył ostatecznie do Królestwa Polskiego Władysław II Jagiełło. W okresie staropolskim nie wykształciła się tu pełna hierarchia urzędnicza, dlatego zachowany został status ziemi, powiązanej administracyjnie z województwem sieradzkim (Szczygielski 1969: 15-17). Zasięg terytorialny ziemi wieluńskiej w dużym stopniu wyznaczały doliny rzek: od północy Barycz i Oleśnicy, na południu górnego biegu Prosny i Liswarty, a na wschodzie Warty. Ziemia wieluńska od późnego średniowiecza dzieliła się na dwa powiaty: wieluński i ostrzeszowski, rozdzielone rzeką Prosną. Wszystkie badane obiekty sakralne zlokalizowane były w okresie swego powstawania na obszarze powiatu wieluńskiego. Współcześnie powiat wieluński, leżący w obrębie województwa łódzkiego, ma zdecydowanie mniejszy zasięg przestrzenny. W jego granicach zlokalizowane są badane kościoły w Gaszynie i Kadłubie (gm. Wieluń), Grębieniu i Popowicach (gm. Pątnów), Łaszewie (gm. Wierzchlas) oraz Naramicach i Wiktorowie (gm. Biała). Kościół w Starym Ochędzynie usytuowany jest na terenie sąsiedniego powiatu wieruszowskiego (gm. Sokolniki), ale nadal w graniach województwa łódzkiego. Dwa obiekty sakralne reprezentujące badaną kategorię znajdują się natomiast na obszarze obecnego województwa opolskiego, w powiecie oleskim, kościół w Jaworznie - w gminie Rudniki, zaś kościół w Wierzbiu - w gminie Praszka (ryc. 2). 


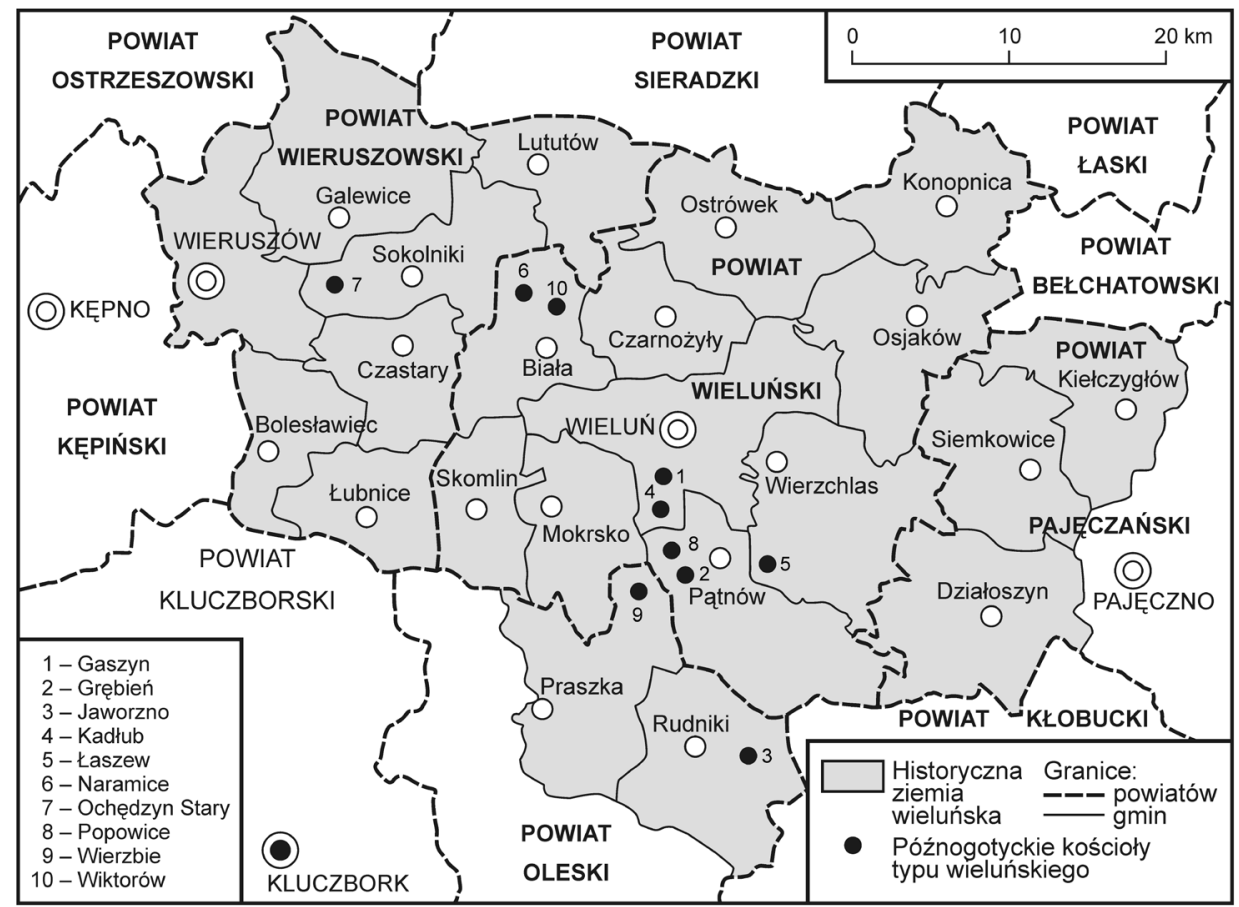

Ryc. 2. Lokalizacja zidentyfikowanych późnogotyckich kościołów typu wieluńskiego Źródło: oprac. własne

Z punktu widzenia genezy analizowanych świątyń istotne znaczenie ma również lokalizacja w zakresie terenowej administracji kościelnej. W średniowieczu i epoce wczesnonowożytnej był to obszar oddziaływania arcybiskupstwa gnieźnieńskiego. Jednostką niższego szczebla były archidiakonaty. Zasięg terytorialny archidiakonatu rudzkiego, a w późniejszym czasie wieluńskiego odpowiadał w przybliżeniu ówczesnym granicom administracji państwowej. Podział na dekanaty w archidiakonacie wieluńskim dokonał się po synodzie diecezjalnym w Łowiczu 4 października 1583 roku (Synodus archidiocesana Gnesnensis..., 1872: 41). Utworzono wtedy trzy dekanaty: rudzki, wieruszowski i krzepicki. W świetle wizytacji z połowy XVII wieku na terenie dekanatu rudzkiego znajdował się omawiany wcześniej kościół parafialny w Kadłubiu wraz z filiami w Grębieniu i Popowicach, kościół parafialny w Łaszewie, kościół filialny w Wierzbiu, należący do parafii w Ożarowie oraz kościół filialny w Gaszynie podporządkowany parafii wieluńskiej. Na obszarze dekanatu wieruszowskiego usytuowany był kościół filialny w Wiktorowie powiązany z Białą, kościół parafialny w Naramicach oraz kościół w Ochędzynie, stanowiący filię świątyni w Sokolnikach. Kościół w Jaworznie, będący ówcześnie filią Parzymiechów leżał 
natomiast na obszarze dekanatu krzepickiego (Zabraniak 2004: 36-37). Podstawową jednostkę administracji kościelnej stanowią parafie. Na terenie ziemi wieluńskiej w okresie przedrozbiorowym istniało ich kilkadziesiąt. Jak wynika z wcześniejszych analiz, istnieją przesłanki źródłowe, by twierdzić, że co najmniej w XV wieku funkcjonowały już parafie w Jaworznie, Kadłubie, Łaszewie, Naramicach i Wierzbiu. Na przełomie XV i XVI wieku liczba tych jednostek przestrzennych uległa zmniejszeniu, co było spowodowane zbyt słabym uposażeniem niektórych kościołów. W ten sposób za czasów arcybiskupa Jana Łaskiego parafia w Jaworznie została wcielona do Parzymiechów, a parafia w Wierzbiu stała się filią parafii w Ożarowie. Oba obiekty ponownie stały się parafiami na początku XX wieku. Kościoły w Kadłubie i Łaszewie straciły czasowo status parafialny dopiero w XIX wieku, przy czym w obu przypadkach nastąpiła później restytucja dawnej formy działania. Kościoły w Gaszynie, Grębieniu, Ochędzynie, Popowicach i Wiktorowie od samego początku były natomiast świątyniami filialnymi. Niektóre z nich (Grębień, Popowice) kilkakrotnie zmieniały w XIX wieku przynależność parafialną. Dawne kościoły filialne w Gaszynie i Ochędzynie zostały podniesione do rangi parafii w XX wieku, pozostałe zaś (Grębień, Popowice i Wiktorów) do dziś mają status filii. W XIX i XX wieku wielokrotnie zmieniano podziały administracji kościelnej. Wraz z powstaniem diecezji częstochowskiej wszystkie badane kościoły znalazły się w jej obrębie. Za sprawą bulli papieża Jana Pawła II Totus Tuus Poloniae Populus w 1992 roku jeden z badanych obiektów, tj. kościół w Ochędzynie, zmienił przynależność diecezjalną i został objęty granicami nowo utworzonego biskupstwa kaliskiego.

Przyjrzyjmy się teraz kwestii stosunków osadniczo-własnościowych i genezie badanych obiektów. Zachowane do dziś późnogotyckie kościoły drewniane na obszarze ziemi wieluńskiej zostały zbudowane w miejscowościach powstałych od I połowy XIII wieku do przełomu XIV i XV wieku. Trzeba wyraźnie podkreślić, że na podstawie przesłanki dotyczącej pierwszego zapisu źródłowego nie można w większości przypadków w sposób precyzyjny ustalić dokładnej daty powstania osady. Tylko w jednym z dziesięciu analizowanych obiektów istnieje możliwość dokładnego określenia czasu utworzenia wsi. Wyjątek ten odnosi się do miejscowości Wierzbie, w przypadku której dysponujemy wzmianką na temat aktu lokacyjnego in cruda radice. Dla pozostałych osad zachowały się jedynie informacje w aktach o sprzedaży lub ofiarowaniu gruntów (Gaszyn, Popowice, Ochędzyn, Grębień), potwierdzeniu posiadanych dóbr (Kadłub), opłat dziesięcinnych (Jaworzno) lub w innych dokumentach, które poświadczane były przez osoby piszące się z danych miejscowości (Wiktorów, Naramice, Łaszów). Wiadomo, że osady te musiały istnieć odpowiednio wcześniej, aniżeli pierwszy raz wymieniane były ich nazwy w zachowanych materiałach źródłowych. Chronologicznie rzecz ujmując, do najstarszych wsi spośród omawianych zaliczyć można: Popowice, Ochędzyn i Jaworzno, które znane są z zapisek źródłowych z okresu przed 
1250 rokiem. Nieco młodsze są zapewne wsie: Grębień i Gaszyn, o których czerpiemy informacje na podstawie źródeł z końca XIII i pierwszej połowy XIV wieku. Największy rozwój osadnictwa nastąpił natomiast w II połowie XIV wieku, a zwłaszcza za rządów Władysława Opolczyka. Z tego okresu dowiadujemy się po raz pierwszy o istnieniu Kadłubia (1357), Wierzbia (1381), Łaszewa (1386) i Naramic (1395). Najmłodszą osadą wydaje się być Wiktorów, o którym pierwsza wzmianka pochodzi dopiero z 1404 roku. Najprawdopodobniej aż 7 spośród 10 badanych wsi przeszło lokację na prawie niemieckim, o czym świadczą zapiski na temat przeprowadzonej lokacji (Grębień, Ochędzyn, Wierzbie) bądź informacje o sprzedaży lub odnowieniu wójtostwa (Kadłub) oraz nadziałach sołtysich (Jaworzno, Naramice, Popowice).

Warto przeanalizować również strukturę własnościową badanych miejscowości. W okresie staropolskim możemy mówić o trzech głównych kategoriach własności ziemskiej: monarszej, duchownej i szlacheckiej. W połowie XVI wieku na obszarze ziemi wieluńskiej zidentyfikowano 41 osad królewskich (18,1\% ogółu), 35 osad kościelnych (15,5\% ogółu) i 150 osad szlacheckich (66,4\% ogółu) (Atlas historyczny Polski..., 1998: 63). Gdy mowa o osadach, w których zachowały się badane kościoły, struktura wygląda nieco inaczej, gdyż $\mathrm{w}$ porównaniu do przedstawionego ujęcia makroskalowego dostrzec można większy udział wsi należących do Kościoła. Otóż w XVI wieku mamy do czynienia z jedną wsią królewską (Wierzbie), czterema wsiami duchownymi (Grębień, Kadłub, Ochędzyn i Popowice) oraz pięcioma wsiami szlacheckimi (Gaszyn, Jaworzno, Łaszew, Naramice i Wiktorów). Trzeba wyraźnie podkreślić, że własność kościelna nie stanowi grupy jednolitej. Mianowicie dwie wsie (Grębień i Kadłub) należały do kapituły gnieźnieńskiej i zostały jej przekazane przez arcybiskupa w połowie XVI wieku, jedna wieś w całości (Popowice) podlegała kapitule kolegiaty wieluńskiej, a jedna wieś (Ochędzyn) stanowiła część dóbr ziemskich klasztoru cysterek z Ołoboku. Gwoli ścisłości warto dodać, że w Gaszynie, jako wsi w przeważającej części należącej do szlachty, folwark posiadał również dziekan wieluński. Analizując dane z rejestrów poborowych z połowy XVI wieku, można stwierdzić, że wsie, w których powstawały w tym czasie drewniane kościoły znacznie różniły się od siebie pod względem wielkości, biorąc pod uwagę stopień zaludnienia. Najwięcej kmieci odnotowano w Naramicach (34), Jaworznie (20) i Gaszynie (19). Najczęściej wsie obejmowały 13-14 gospodarstw kmiecych (Grębień, Kadłub, Łaszew, Ochędzyn, Popowice). Najmniej ludną wsią był Wiktorów, gdzie odnotowano w tym czasie tylko 4 kmieci.

Bardzo trudno określić dokładnie moment powstania badanych świątyń z uwagi na brak jednoznacznych podstaw źródłowych. Materiały opisowe potwierdzają fakt istnienia kościołów w XVI wieku, ale nie podają precyzyjnych danych na temat ich budowy, która zapewne następowała wieloetapowo. W sukurs częściowo przychodzą wyniki badań architektonicznych. Dzięki analizom 
polichromii oraz pozostałych elementów wyposażenia, udało się potwierdzić datowanie większości kościołów, które dokonane zostało uprzednio na podstawie innych przesłanek historycznych. Biorąc pod uwagę współczesne umiejscowienia kościołów należy stwierdzić, że w większości przypadków znajdują się one w centralnych częściach wsi (np. Gaszyn, Grębień, Popowice) lub w peryferyjnych strefach siedlisk (np. Łaszew, Naramice, Wiktorów). Trzeba podkreślić, że obecna ich lokalizacja w stosunku do zabudowy często nie jest zgodna $\mathrm{z}$ historyczną, albowiem o ile świątynie pozostawały in situ, o tyle wsie podlegały regulacji w XIX wieku, a w przypadku wielu z nich miała ona charakter całkowitej metamorfozy pierwotnego rozplanowania. Badane kościoły zazwyczaj usytuowane są w głębi działek, w pewnej odległości od drogi wiejskiej. Dość często otoczone są dawnymi nagrobkami, starodrzewiem, a zasięg terenu przykościelnego wyznacza drewniane lub murowane ogrodzenie.

Kolejna kwestia, którą należy rozważyć to charakterystyka fizjonomiczna badanych kościołów, w tym aspekty konstrukcyjno-dekoracyjne, świadczące o współczesnych walorach dziedzictwa kulturowego. Jak wspomniano w części wstępnej, można wyróżnić zespół cech swoistych, które mają charakter uniwersalny dla badanego zbioru kościołów, a które wyróżniają je od innych obiektów sakralnych. Abstrahując od zagadnienia metryki historycznej, która została już omówiona, warto przyjrzeć się specyfice architektonicznej świątyń typu wieluńskiego. Otóż kościoły reprezentujące analizowaną odmianę to obiekty orientowane, a więc z prezbiterium skierowanym na wschód. Wszystkie kościoły zbudowane są w całości lub w zasadniczym stopniu z drewna. Główne elementy korpusu budowli wykonane są w konstrukcji zrębowej. W wielu z nich integralnym elementem części frontalnej są wieże zbudowane w konstrukcji słupowej. Budowle są z zewnątrz oszalowane. Podstawowym elementem stanowiącym cechę rozpoznawczą jest dach, z reguły jednokalenicowy, dwuspadowy, kryty gontem. Pokrywa on w całości zarówno nawę, jak i prezbiterium kościoła. Biorąc pod uwagę fakt, że prezbiterium, najczęściej zwieńczone wielobocznie, jest w świątyniach wieluńskich węższe od nawy, powstaje charakterystyczny, szeroki okap wysunięty wokół prezbiterium. Do nawy przylega jedna lub dwie kruchty, a do prezbiterium zakrystia. Oprócz wskazanych cech pierwotnych stanowiących podobieństwa, można wyróżnić elementy wtórne, a także wyszczególnić różnice występujące między badanymi kościołami, które wynikają najczęściej z wielu, zachodzących przez stulecia prac remontowych i konserwacyjnych oraz zmian wywołanych czynnikami naturalnymi i antropogenicznymi. W wyniku licznych prac modernizacyjnych świątynie zyskiwały najczęściej nowy szalunek i pokrycie gontem. Biorąc pod uwagę aspekt konstrukcji i rozplanowania, należy podkreślić, że niektóre obiekty nigdy nie obejmowały lub w wyniku przebudowy zatraciły charakterystyczne wieże w części frontalnej, a wydłużeniu uległy nawy. Dotyczyło to kościołów w Kadłubie, Naramicach, Ochędzynie i Wiktorowie. 
W przypadku świątyni w Kadłubie, na skutek prac rewaloryzacyjnych przeprowadzonych na początku XXI wieku, udało się zrekonstruować zlikwidowaną po II wojnie światowej wieżę. W odniesieniu do niektórych świątyń kruchty lub zakrystie są chronologicznie późniejsze w stosunku do pozostałych części. Powstawały one w różnych okresach, od XVIII wieku (np. kruchta w Naramicach) do XX wieku (np. zakrystia w Gaszynie) i mają zazwyczaj formę stylizowaną. Wyjątkiem jest kościół w Wierzbiu, w którym jedna z zakrystii, jako forma dysharmonijna, jest murowana i otynkowana. Kościół w Jaworznie zyskał natomiast w dwóch etapach kaplice boczne, które zmieniły ostatecznie kształt całego obiektu. Jeśli chodzi o wyposażenie wnętrz to $\mathrm{w}$ analizowanych świątyniach zachowały się tylko nieliczne elementy z XVI wieku. Niekiedy są to fragmenty polichromii (np. w Grębieniu) oraz pojedyncze obrazy i rzeźby (np. w Grębieniu, Łaszewie, Naramicach, Ochędzynie, Wierzbiu i Wiktorowie). W większości przypadków ołtarze mają charakter późnorenesanowy (np. w Gaszynie, Ochędzynie, Popowicach) lub częściej barokowy (np. Kadłubie, Łaszewie, Naramicach, Wierzbiu).

Późnogotyckie kościoły typu wieluńskiego tworzą homogeniczny, zwarty przestrzennie i specyficzny pod względem fizjonomicznym zbiór obiektów sakralnych. Biorąc po uwagę bardzo długą metrykę i wyjątkowe cechy stylowe, wykazują one wybitne walory kulturowe w skali całego kraju, a nawet Europy. Wymagają zatem szczególnej troski ze strony decydentów na różnych szczeblach administracji publicznej, władz kościelnych, instytucji odpowiedzialnych za ochronę zabytków oraz społeczności lokalnych. Konieczne jest wdrożenie spójnego programu kompleksowej opieki konserwatorskiej nad tymi obiektami. Istnieje przy tym potrzeba dalszych badań oraz realizacji działań rewaloryzacyjnych. Postuluje się objęcie całego zbioru zachowanych kościołów typu wieluńskiego, adekwatną do ich wartości kulturowej, formą ochrony poprzez nadanie statusu pomnika historii oraz rozważenie, wzorem drewnianych świątyń południowej Małopolski, zainicjowania procedury wpisu na Listę Światowego Dziedzictwa UNESCO.

\section{Literatura}

Atlas historyczny Polski, Województwo sieradzkie i województwo tęczyckie w drugiej potowie XVI wieku, cz. 2: Komentarz, indeksy, 1998, H. Rutkowski (red.), Warszawa.

Bąbka-Horbacz E., 1996, Kościót w Laszewie. Historia jednego remontu, „Na Sieradzkich Szlakach", 4: 12-15.

Białas Z., 2008, Kościót św. Barbary w Wieluniu od czasów najdawniejszych do wspótczesnych, Wieluń.

Brykowski R., 1981, Drewniana architektura kościelna XV wieku w Małopolsce, Wroclaw. 
Brykowski R., 1994, Polskie kościoły drewniane: straty wojenne - straty pokojowe: Wotyń i Wieluńskie „Ochrona Zabytków”, 47(2): 158-167.

Brykowski R., 2001, Wielkopolskie kościoły drewniane, Poznań.

Brykowski R., Kornecki M., 1984, Drewniane kościoły w Małopolsce Południowej, Wrocław.

Budownictwo drzewne, 1905, Materyały: wydawnictwo Towarzystwa „Polska Sztuka Stosowana", z. 6, Kraków.

Chrzanowski T., Piwocki K., 1981, Drewno w polskiej architekturze i rzeźbie ludowej, Wrocław.

Ciekliński Z., 1963, Zabytki Ziemi Wieluńskiej, Łódź.

Cieślak E., 2014a, Kościół pw. Najświętszego Imienia Maryi w Gaszynie, Portal Narodowego Instytutu Dziedzictwa, https://zabytek.pl/pl/obiekty/gaszyn-kosciol-pw-najswietszego-imienia-maryi (dostęp: 1.06.2020).

Cieślak E., 2014b, Kościół pw. św. Anny w Starym Ochędzynie, Portal Narodowego Instytutu Dziedzictwa, https://zabytek.pl/pl/obiekty/stary-ochedzyn-kosciol-pw-sw-anny (dostęp: 1.06.2020).

Cieślak E., 2014c, Kościót pw. Wszystkich Świętych w Naramicach, Portal Narodowego Instytutu Dziedzictwa, https://zabytek.pl/pl/obiekty/naramice-kosciol-pw-wszystkich-swietych (dostęp: 1.06.2020).

Codex Diplomaticus Silesiae, 1884, t. 7, cz. 1: Regesten zur schlesischen Geschichte. Bis zum Jahre 1250, Breslau.

Czerwiński T., 2010, Budownictwo ludowe w Polsce, Warszawa.

Domagała K., 2004, Zabytki staropolskiego budownictwa drewnianego w Skomlinie, „Rocznik Wieluński”, 4: 211-216.

Emmerling D., Wierzgoń A., 2006, Opolskie kościoły drewniane, Opole.

Inwentarz drewnianej architektury sakralnej w Polsce, 1993, R. Brykowski (red.), z. 4b: Kościoły w Wielkopolsce XVI w., Warszawa.

Joannis de Lasco Liber beneficiorum archidioecesis Gnesnensis, 1881, t. 2, wyd. J. Łukomski, Poznań.

Joannis Dlugossii Senioris Canonici Cracoviensis Opera omnia, 1864, t. 9, Liber beneficiorum dioecesis cracoviensis, t. 3, Kraków.

Kalbarczyk-Klak E., 2014a, Kościół par. pw. św. Leonarda w Wierzbiu, Portal Narodowego Instytutu Dziedzictwa, https://zabytek.pl/pl/obiekty/wierzbie-kosciol-par-pw-sw-leonarda (dostęp: 1.06.2020).

Kalbarczyk-Klak E., 2014b, Kościół pw. Świętej Trójcy w Jaworznie, Portal Narodowego Instytutu Dziedzictwa, https://zabytek.pl/pl/obiekty/jaworzno-kosciol-pw-swietej-trojcy (dostęp: 1.06.2020).

Katalog zabytków sztuki w Polsce, 1953, t. II: Województwo łódzkie, J. Łoziński (red.), z. 12: Powiat wieluński, oprac. H. Hohensee-Ciszewska, B. Wolff, Warszawa.

Kodeks dyplomatyczny Wielkopolski, 1877, t. 1; 1878, t. 2; 1879, t. 3, wyd. I. Zakrzewski, Poznań. 
Kornecki M., 1992, Drewniana architektura sakralna w Polsce: zagadnienie typów i form regionalnych w rozwoju historycznym, „Ochrona Zabytków”, 45(1-2): 7-31.

Korytkowski J., 1889, Arcybiskupi gnieźnieńscy: prymasowie i metropolici polscy od roku 1000 aż do roku 1821, czyli do połaczenia arcybiskupstwa gnieźnieńskiego z biskupstwem poznańskim, t. 3, Poznań.

Krassowski W., 1961, Architektura drewniana w Polsce, Warszawa.

Langner D., 2014, Bursztynowym szlakiem drewnianych kościołów, Warszawa.

Lorenc-Karczewska A., 2014a, Kościót filialny pw. św. Jadwigi i św. Trójcy, ob. pw. św. Trójcy, Portal Narodowego Instytutu Dziedzictwa, https://zabytek.pl/pl/obiekty/ grebien-kosciol-filialny-pw-sw-jadwigi-i-sw-trojcy-ob-pw-s (dostęp: 1.06.2020).

Lorenc-Karczewska A., 2014b, Kościół parafialny pw. św. Jana Chrzciciela w Łaszewie, Portal Narodowego Instytutu Dziedzictwa, https://zabytek.pl/pl/obiekty/laszew-kosciol-parafialny-pw-sw-jana-chrzciciela (dostęp: 1.06.2020).

Łoziński J.Z., 1952, Zabytki powiatów radomszczańskiego i wieluńskiego. Sprawozdanie z objazdu inwentaryzacyjnego, „Biuletyn Historii Sztuki”, 2: 79-80.

Łoziński J.Z., Miłobędzki A.J., 1967, Atlas zabytków architektury w Polsce, Warszawa.

Matuszczak J., 1975, Kościoły drewniane na Śląsku, Wrocław.

Olejnik T., 1980, Wieluń i okolice, Wieluń.

Patykiewicz W., 1957, Archidiakonat wieluński, „Częstochowskie Wiadomości Diecezjalne", 10: 425-432.

Patykiewicz W., 1958, Archidiakonat wieluński, „Częstochowskie Wiadomości Diecezjalne", 7: 275-283.

Pawlaczyk M., 1984, Architektura szesnastowiecznych kościołów drewnianych z terenu Wielkopolski, „Rocznik Historii Sztuki”, 14: 105-144.

Polska XVI wieku pod względem geograficzno-statystycznym. Wielkopolska, 1883, t. 2, Źródła Dziejowe, t. 13, wyd. A. Pawiński, Warszawa.

Raport o stanie zachowania zabytków nieruchomych w Polsce. Zabytki wpisane do rejestru zabytków (księgi rejestru A i C), 2017, M. Rozbicka (red.), Warszawa.

Rączka J.W., 1990, Architektura drewniana, Kraków.

Rosin R., 1961, Ziemia wieluńska w XII-XVI w. Studia z dziejów osadnictwa, Łódź.

Rosin R., 1963, Słownik historyczno-geograficzny ziemi wieluńskiej w średniowieczu, Warszawa.

Ruszczyk G., 2007, Drewno i architektura, Warszawa.

Ruszkowski A., 1992, Piękno w modrzewiu zaklęte, Sieradz.

Słownik geograficzny Królestwa Polskiego i innych krajów słowiańskich, 1882, t. 3; 1887, t. 8, F. Sulimierski, B. Chlebowski (red.), Warszawa.

Strzelecki G., 2006, Zabytkowe obiekty drewniane województwa tódzkiego. Stan techniczny na przełomie XX $i$ XXI wieku, Łódź.

Synodus archidiocesana Gnesnensis Lovicii MDLXXXIII celebrata, 1872, wyd. Z. Chodyński, Warszawa. 
Szczygielski W., 1969, Dzieje ziemi wieluńskiej, Łódź.

Tłoczek I., 1980, Polskie budownictwo drewniane, Wrocław.

Wizytacje dóbr arcybiskupstwa gnieźnieńskiego i kapituly gnieźnieńskiej w XVI wieku, 1920, wyd. B. Ulanowski, Kraków.

Wolf-Łozińska B., 1953, Polichromia stropu w Grębieniu. Z zagadnień przełomu gotyku i renesansu w Polsce, „Biuletyn Historii Sztuki”, 15(2): 7.

Zabraniak S., 2004, Wieluński ośrodek kościelny w okresie staropolskim, Lublin.

Zabraniak S., 2015, Z dziejów miejscowości i parafii Gaszyn, „Veritati et Caritati”, 4: 419-438.

\title{
Late Gothic churches of the Wielun type - the problem of identification, genetic and settlement determinants and present contemporary cultural values
}

\begin{abstract}
The chapter concerns the problem of identification, genetic and settlement conditions, and present cultural values of late Gothic wooden churches representing the Wielun type. It is a homogeneous collection from the sixteenth century, specific in terms of location and physiognomy. As a result of the discussion on the classification criteria, 10 preserved objects of this type were identified. Based on historical sources and literature, an analysis of the origins of the studied group of historic buildings was carried out, taking into account the issues of church administration, settlement and ownership relations. Then, the location and architectural features of the churches were examined, taking into account the variability and preservation of historic structural and decorative forms. The analyzed objects are characterized by outstanding cultural values and therefore require special care and implementation of complex actions in the field of legal protection and conservation.
\end{abstract}

Keywords: church, Wielun Land, $16^{\text {th }}$ century, settlement, cultural heritage.

Dr Tomasz Figlus

Uniwersytet Łódzki

Wydział Nauk Geograficznych

Katedra Geografii Politycznej, Historycznej i Studiów Regionalnych

e-mail: tomasz.figlus@geo.uni.lodz.pl

(D) https://orcid.org/0000-0001-9892-8314 